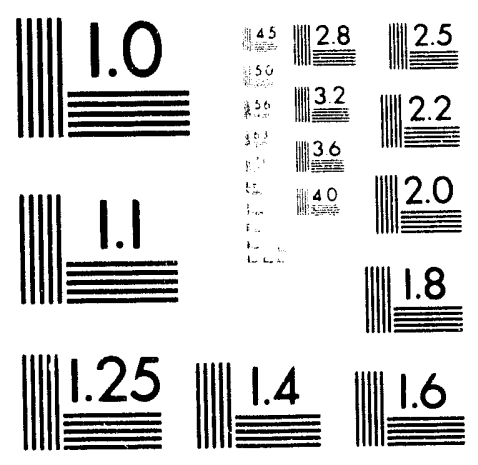



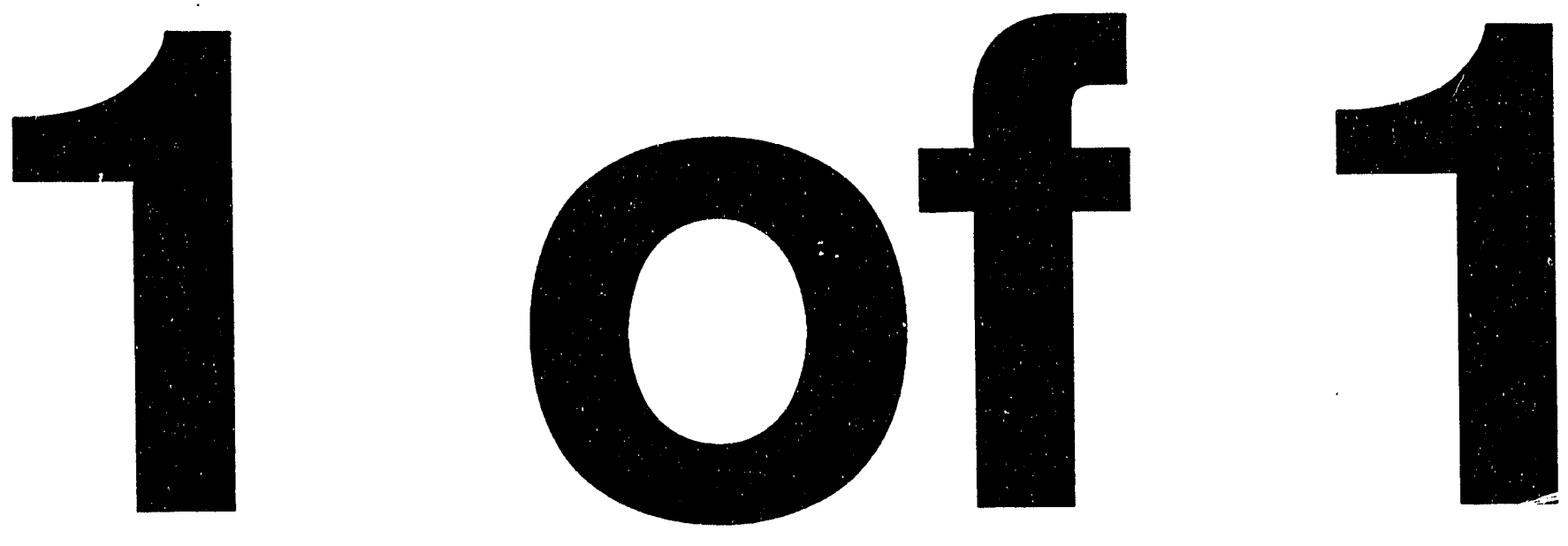
DOE/RL-93-27

Revision 0

UC-630

\section{Treatability Test Plan for the 200-BP-1 Prototype Surface Barrier}

Date Published

June 1993

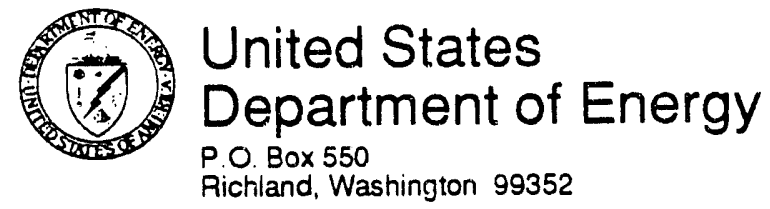

Approved for Public Release

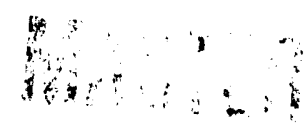


DOE/RL-93-27, Rev. 0

\section{ACRONYMS}

$\begin{array}{ll}\text { ARAR } & \text { applicable or relevant and appropriate requirements } \\ \text { BDT } & \text { Barrier Development Team } \\ \text { CERCLA } & \text { Comprehensive Environmental Response, Compensation, and } \\ \text { Liability Act of } 1980 \\ \text { DQO } & \text { data quality objective } \\ \text { DOE } & \text { U.S. Department of Energy } \\ \text { EPA } & \text { U.S. Environmental Protection Agency } \\ \text { ER } & \text { environmental restoration } \\ \text { FLTF } & \text { Field Lysimeter Test Facility } \\ \text { FS } & \text { feasibility study } \\ \text { HPT } & \text { Health Physics Technician } \\ \text { ITS } & \text { in-tank-solidification } \\ \text { KEH } & \text { Kaiser Engineers Hanford Company } \\ \text { LRB } & \text { laboratory record books } \\ \text { NPL } & \text { National Priority List } \\ \text { PNL } & \text { Pacific Northwest Laboratory } \\ \text { RCRA } & \text { Resource Conservation and Recovery Act of } 1976 \\ \text { RI } & \text { remedial investigation } \\ \text { RL } & \text { Richland Operations } \\ \text { ROD } & \text { record of decision } \\ \text { STLF } & \text { Small Tube Lysimeter Facility } \\ \text { TBC } & \text { to-be-considered } \\ \text { Tri-Party } & \text { Hanford Federal Facility Agreement and Consent Order } \\ \text { Agreement } & \\ \text { QA } & \text { quality assurance } \\ \text { QC } & \text { quality control } \\ \text { WHC } & \text { Westinghouse Hanford Company } \\ & \end{array}$ 


\section{CONTENTS}

1.0 INTRODUCTION

1.1 PURPOSE AND SCOPE

1.2 SITE SELECTION

1.3 SITE CONDITIONS AND CONTAMINATTION

2.0 TEST PERFORMANCE AND DATA QUALITY OBJECTIVES . . . . . . . . . . . . 6

2.1 GOALS AND OBJECTIVES . . . . . . . . . . . . . . . 6

2.2 DATA QUALITY OBJECTIVES

3.0 POTENTIALLY APPLICABLE OR RELEVANT AND APPROPRIATE

REQUIREMENTS .......................... . . . . . 7

4.0 EXPERIMENTAL DESIGN •. . . . . . . . . . . . . . . . 8

4.1 BARRIER FUNCTIONAL DESCRIPTION AND PERFORMANCE . . . . . . . . . . 8

4.2 TREATABILITY TEST PLAN . . . . . . . . . . . . . . . . . . 9

4.2.1 Treatability Test Pian Phase I: Design
and Construction . . . . . . . . . 16

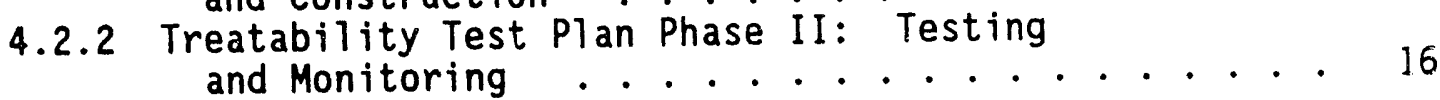

5.0 RESIDUALS MANAGEMENT .......................... 18

6.0 REPORTS .. . . . . . . . . . . . . . . . . . . . 18

6.1 CONSTRUCTION REPORT. . . . . . . . . . . . . . . 18

6.2 TESTING AND MONITORING REPORTS . . . . . . . . . . . . . . . . 19

7.0 PROJECT MANAGEMENT . . . . . . . . . . . . . . . . . 19

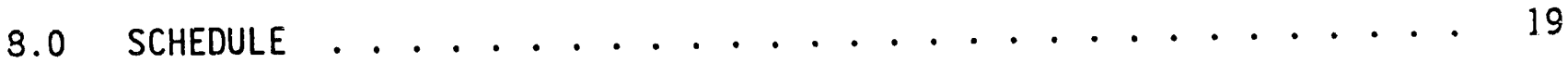

9.0 REFERENCES . . . . . . . . . . . . . . . . . . . . . 26

APPENDIX A - PUBLISHED PERMANENT ISOLATION BARRIER DOCUMENTS . . . . . . 27

\section{FIGURES:}

1-1 Hanford Site Map .. . . . . . . . . . . . . . . . . . 2

1-2 200-BP-1 Location Map . . . . . . . . . . . . . . . . . . 13

4-1 Transport Pathways t jontroi Pathways . . . . . . . . . . . . . . . . . 14

4-2 Engineered Barrier to Control Pathways . . . . . . . . . . . . . . . . 14

4-3 Prototype Barrier Cross-Section . . . . . . . . . . . . . . . . . 25

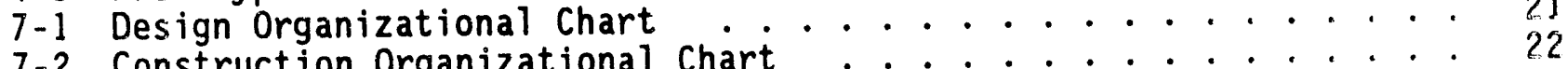

7-2 Construction Organizational Chart

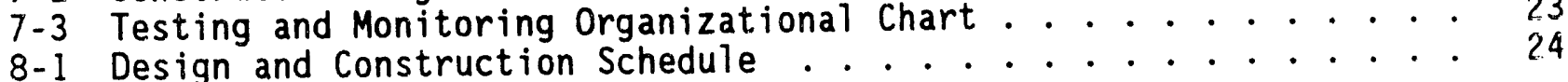

\section{TABLES:}

3-1 Potential ARAR to be Considered ................ 10

3-2 Potential ARAR for Covers .................. 12 


\subsection{INTRODUCTION}

The U.S. Department of Energy (DOE), Hanford Site, in Washington State is organized into numerically designated operational areas including the 100 , $200,300,400,600$, and 1100 Areas. The U.S. Environmental Protection Agency (EPA), in November of 1989, included the 200 Areas of the Hanford Site on the National Priority List (NPL) under the Comprehensive Environmental Response, Compensation, and Liability Act of 1980 (CERCLA). The 200 Area is divided into operable units based on waste disposal information, location, facility, type, and other characteristics. The 200-BP-1 operable unit is one specific site located within the 200 East Area (Figure 1-1).

Inclusion on the NPL initiated the remedial investigation (RI) process for characterizing the nature and extent of contamination and assessing risks to human health and the environment at the 200-BP-1 operable unit. These efforts are being addressed through the Hanford Federal Facility Agreement and Consent Order (Ecology et al., 1989), which was negotiated and approved by the $D O E, E P A$, and Washington Department of Ecology (Ecology) in May of 1989. This agreement, known as the Tri-Party Agreement, governs al1 CERCLA efforts at Hanford. In March of 1990 , a remedial investigation/feasibility study (RI/FS) work plan for the 200-BP-1 operable unit was issued (DOE-RL 1990a). The work plan outlined the first phase of site characterization activities, which were completed in March of 1993 with the issuance of Phase I Remedial Investigation Report for the 200-BP-1 Operable Unit (DOE-RL 1993, Draft A).

Remedial action objectives outlined in the RI report suggest that a 1 ikely remedial action at the 200-BP-1 operable unit could involve the use of a surface barrier. To further evaluate this technology, additional performance and constructability data are needed to implement this remedial action.

This test plan describes the general methodology for conducting a prototype barrier treatability study. The objectives of this treacability study are to determine overall performance and constructability data on an actual waste site in conjunction with the Hanford Site Barrier Development Program.

This test plan has been developed in accordance with guidance provided in the Guide for Conducting Treatability Studies Under CERCLA (EPA 1989).

\subsection{PURPOSE AND SCOPE}

Treatability investigations are one of the primary components of the RI/FS process, providing critical performance and cost information needed to evaluate and select appropriate treatment alternatives. Treatability studies are also used to provide critical design information necessary to implement the selected remedy. 
Figure 1-1. Hanford Site Map.

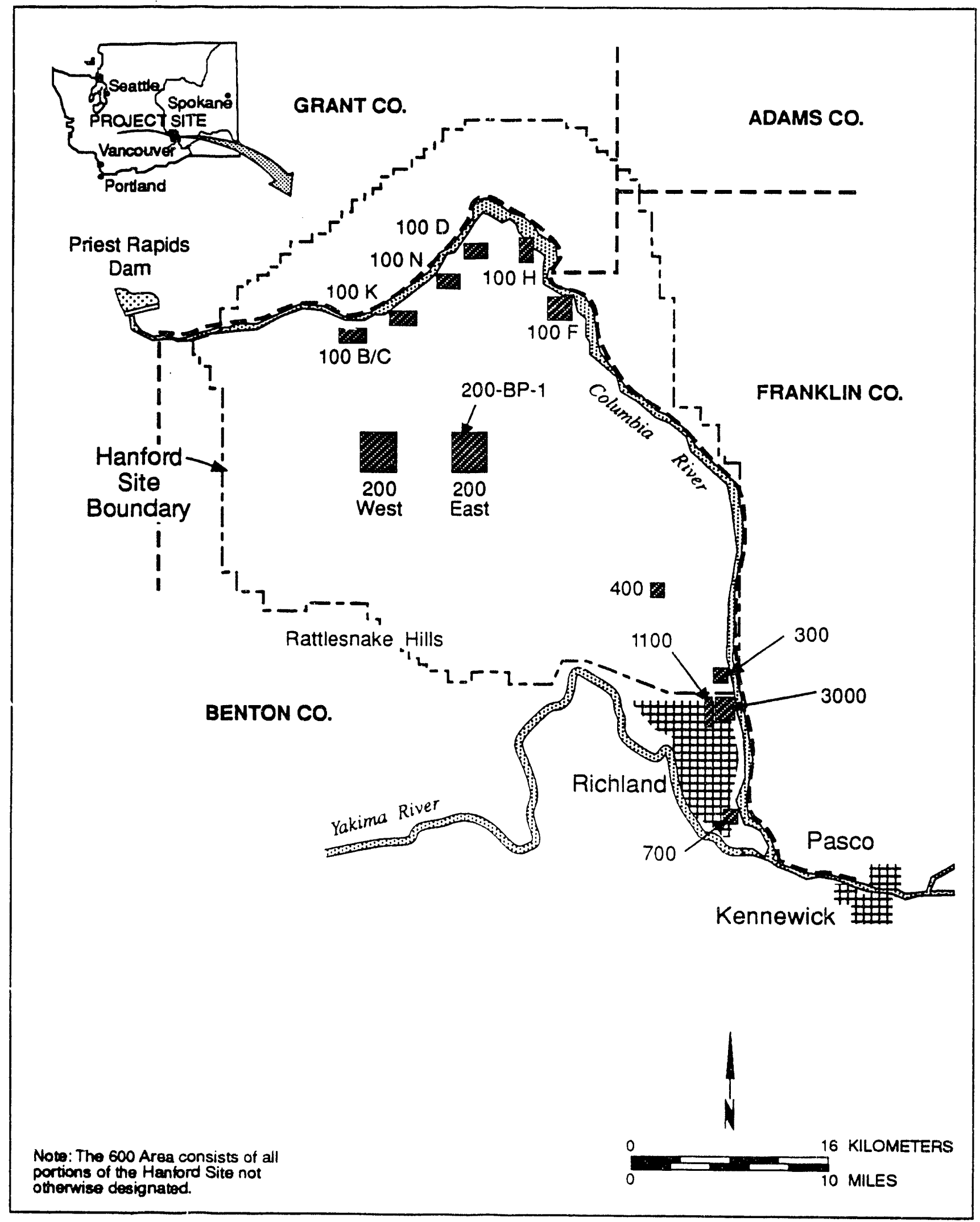

$9131764 / 28892 / 1-6-93$ 
Treatability studies fall into either of two broad categories; prerecord of decision (ROD) and post-ROD. Pre-ROD treatability studies are typical?y conducted when there is limited, or possibly no, information on the performance and cost of a remedial action alternative and more data are needed to support the evaluation of the alternative during the FS. Post-ROD treatability studies provide detailed design, cost, and performance data needed to optimize treatment processes and implement full-scale treatment systems following a remedial action decision. Post-ROD treatability studies are typically conducted to obtain information required to support the preparation of detailed design specifications for treatment trains and may be used to prequalify vendors and processes.

This test plan is considered a pre-ROD treatability study. The purpose of the study is to document all necessary functional performance requirements and their associated costs for implementing the Hanford protective barrier as a potential remedial action to control water infiltration; plant, and animal intrision; wind and water erosion; and noxious gas emissions from waste disposal sites. The Hanford barrier was selected over conventional Resource Conservation and Recovery Act of 1976 (RCRA) clay cover designs for the study based on the following considerations:

- Certain types of waste at Hanford and their associated local hydrolngic, geologic, and climatic conditions may cause RCRA covers to be more susceptible for desiccation cracking.

- The 30-yr design life of the RCRA clay cover design will necessitate a long-term maintenance commitment to ensure that the cover continues to perform as designed.

To address these issues, the Hanford protective barrier is being developed to exceed RCRA clay cover design requirements including 1 ife expectancy, hydraulic conductivity, and overall maintainability.

This treatability study plan includes discussions and descriptions of the following topical areas:

- site selection

- site contaminants

- data quality objectives (DQO)

- potentially applicable or relevant and appropriate requirements (ARAR)

- experimental design

- reporting requirements

- schedule

- program organization.

\subsection{SITE SELECTION}

Hanford protective barrier research and development was initiated in the mid-1980's to optimize individual barrier components to ensure long-term (minimum 1,000 yr) control of water infiltration, biointrusion, erosion, and noxious gas emissions. The nature of the testing has ranged from controlled laboratory experiments (e.g., erosion testing in a wind tunnel) to small-scale field tests that evaluate the one-dimensional flow of meteoric water through 
layered earthen barrier systems and evaluate the impact of surface treatments on near-surface water balance (e.g., water infiltration testing in field lysimeters). Experimental data on barrier performance have been supplemented by observations of natural barrier analogs, which have been in existence for thousands of years, and computer modeling.

To date, barrier performance has been evaluated only through laboratory and small-scale field experiments. Details on these activities can be found in roughly 60 technical publications found in Appendix $A$. A large-scale field exp rimentation is now needed to enable engineers and scientists to obtain field experience in constructing protective barriers and evaluating their performance. Construction issues that were not readily apparent on the engineering drawings may be more easily detectable in the field. Construction of a large-scale prototype barrier will also provide data that can be transferable to larger construction activities for surface barriers on the Hanford Site.

Most of the protective barriers being considered for waste remediation activities at Hanford will be constructed on the 200 Area Plateau. To obtain representative and supportable cost estimates and authentic performance data, construction of the prototype barrier must be completed in this area and on an actual waste site. The 200-BP-1 operable unit in 200 East Area (Figure 1-2) meet these criteria. The prototype barrier treatability test will be conducted at the 216-B-57 crib within the 200-BP-1 operable unit. This waste site is isolated from the majority of the waste sites within the operable unit and will not interfere with the final remediation of the 200-BP-1 operable unit. In addition, an overall cost savings may occur by utilizing the prototype barrier as a final remediation for the 216-B-57 Crib. Final closure for the 216-B-57 Crib will be based on the subsequent ROD for the 200-BP-1 operable unit.

In addition to the site-specific needs of the 200-BP-1 operable unit, construction of the large-scale barrier is important from a Hanford site-wide perspective since other environmental restoration and waste management operations may use the Hanford protective barrier in support of facility closures (e.g, Grout Program, Solid Waste Management Program, Decontamination and Decommissioning Program, and the Environmental Restoration Storage and Disposal Facility).

\subsection{SITE CONDITIONS AND CONTAMINATION}

The 216-B-57 Crib within the 200-BP-1 operable unit received storage condensate waste from the 241-BY Tank Farm between February of 1968 and June of 1973. An in-tank solidification (ITS) process created waste by heating, collecting, and condensing the evaporants within the 241-BY Tank Farm, and discharging the waste underground in the 216-B-57 Crib. The crib construction includes a 12 -in. corrugated and perforated steel pipe that runs the length of the 200-ft-long and 15-ft-wide crib within a gravel infiltration bed. The surface of the crib is fenced as illustrated in Figure 1-2. ITS waste was discharged to the perforated pipe then infiltrated through the gravel and into the natural soils. 
DOE/RL-93-27, Rev. 0

Figure 1-2. The 200-BP-1 Operable Unit.

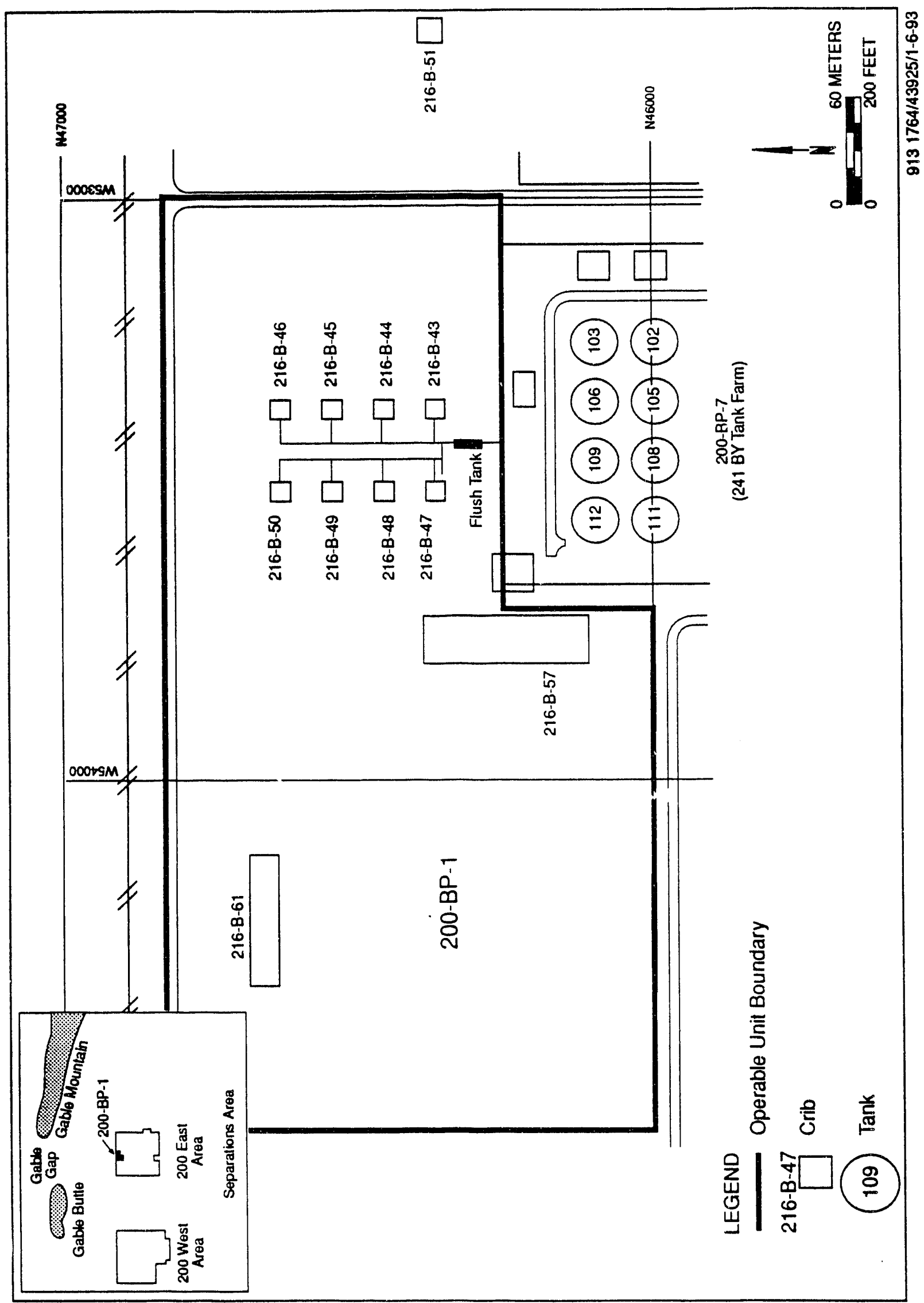


Potential contaminants of concern within the 216-B-57 Crib include: cesium-137, strontium-90, plutonium-238/239, technicium-99, radium-226, cobalt-60, and total uranium. Nonradioactive contaminants include cadmium, nickel, and polychlorinated biphenyls (PCB) (DOE-RL 1993a). The majority of these constituents have low mobility, low concentrations/short half-lives, and are not expected to significantly impact the aquifer. The contaminants wich the highest concentrations are cesium-137 and strontium-90. The majority of contaminants are located at depth of 15 to $30 \mathrm{ft}$ below the ground surface. The depth of groundwater is approximately $230 \mathrm{ft}$ below the ground surface. strontium-90 and cesium-137. Both of these contaminants are bound or sorbed very strongly to the soil particles. The majority of contaminates are located at a depth of 15 to $30 \mathrm{ft}$ below the ground surface. The groundwater is at a depth of approximately $230 \mathrm{ft}$ below the ground surface.

\subsection{TEST PERFORMANCE AND DATA QUALITY OBJECTIVES}

The prototype barrier will be tested and monitored to evaluate its performance over the range of conditions representative of those expected during its design life. It should be noted that the construction of the prototype barrier is, in itself, a test since a barrier of this particular design has never been constructed.

\subsection{GOALS AND OBJECTIVES}

The prototype barrier is a technology that was developed to protect human health and the environment by isolating waste in a semi-arid environment. The structure is designed to function as a barrier by minimizing infiltration or the flow of water past the waste (reduce mobility); preventing plant and animal intrusior, thereby minimizing the effects of water and wind erosion (long-term effectiveness and permanence); and providing a deterrent to human intrusion. Consistent with this overall goal, tice general objectives of the prototype barrier treatability study are summarized as follows:

- Evaluate the effectiveness of the barrier components individually and as they interact to form a complete/whole engineered system.

- Provide large scale testing of phenomena that are not adequately tested on small field plots, in laboratories, or with lysimeters.

- Provide a baseline by demonstrating barrier system performance under both stressed and ambient conditions.

- Document the testing and monitoring activities for the purpose of peer review and critique, regulatory review, and technology transfer.

- Provide a more accurate basis for estimating the costs associated with constructing permanent isolation surface barriers.

- Use the information and insights gained from testing activities to direct future barrier development and construction activities. 
To guide the evaluation of prototype barrier performance, a detailed testing and monitoring plan has been prepared (Gee et al. 1993). This plan contains specific information on the nature and extent of the tests and experiments that will be conducted on the prototype barrier, which includes an evaluation of water infiltration and erosion, wind erosion, and biointrusion.

\subsection{DATA QUALITY OBJECTIVES}

To ensure that the correct level of detail and data quality is achieved to satisfy the objectives discussed in Section 2.1, DQO are defined. These DQO address the need to:

- Collect appropriate data during the construction of the prototype barrier to ensure that the structure has been constructed consistent with the design specifications (verification of design).

- Collect the appropriate data during the monitoring and testing phase of the treatability study to evaluate the performance of the parameters discussed in Section 2.1.

- Collect sufficient data to support Hanford Site remedial action objectives and regulatory approval.

As part of the process for defining DQO, the primary data users and use of the data must be defined (EPA 1987). The primary data users include:

- DOE, EPA, and Ecology remedial project managers, and unit managers.

- Westinghouse Hanford Company (WHC) RI/FS and RCRA facility closure coordinators.

The data will be used to support final remedial and closure decisions that include:

- evaluations of alternative surface barriers and cover designs

- design of covers and surface barriers.

\subsection{POTENTIALLY APPLICABLE OR RELEVANT AND APPROPRIATE REQUIREMENTS}

Section 12](d) of CERCLA, as amended, requires that remedial actions at NPL sites comply with federal and state environmental laws and regulations. This requirement is reiterated in Subpart $E$ of the National $0 i l$ and Hazardous Substances Pollution Contingency Plan (40 CFR Part 300), which establishes the protocol for identifying ARAR. 
Potential ARAR are those substantive, promulgated federal and state environmental requirements that are pertinent to a remedial action. ARAR may specifically address a hazardous substance, pollitant, contaminant, remedial action, location, or other circumstance at the site; or they may be otherwise relevant and appropriate by addressing problems or situations sufficiently similar to those at the site. Only those state standards that are promulgated, are identified by the state in a timely manner, and are more stringent. than federal requirements may be applicable or relevant and appropriate (40 CFR $300.400(\mathrm{~g})(4)$ ).

In addition to ARAR, to-be-considered (TBC) information can be important when it comes to planning. TBC are nonpromulgated criteria, advisories, guidance, and proposed standards that are not legally binding, but may provide useful information or recommended procedures. TBC may be used in the absence of ARAR or where ARAR are not sufficiently protective when developing cleanup goals. TBC identified for the barrier treatability study include DOE orders and local county requirements.

Table 3-1 lists the potential location- and action-specific ARAR and TBC that may be relevant to the design, construction, and testing of the prototype barrier. In addition, the action-specific ARAR that address the design and performance of the prototype barrier are provided in Table 3-2.

\subsection{EXPERIMENTAL DESIGN}

\subsection{BARRIER FUNCTIONAL DESCRIPTION AND PERFORMANCE}

Certain types of waste at the Hanford Site (and elsewhere) may be safely managed using in-place stabilization techniques. As with the 216-B-57 Crib, much of the waste that would be disposed of by in-p? ace stabilization is currently located in relatively shallow subsurface structures such as solid waste burial grounds, tanks, vaults, cribs, etc. Unless protected in some way, the wastes could be transported to the accessible environment via the following pathways (Figure 4-1):

- Water infiltration -- the infiltration and percolation of water through the waste zone resulting in the leaching and subsequent transport of radionuclides and other contaminants to the water table.

- Biointrusion - - the penetration of deep-rooting plants and burrowing animals into the waste zone below. The deep-rooting plants could draw radionuclides and other contaminants into its root system and subsequently translocate the contaminants to the aboveground portion of the plant. The contaminants in the aboveground portion of the plant could then be dispersed by animals that eat the plants or by wind. Animals burrowing directly into the waste zone could contact contaminants and, subsequently, bring them to the surface as part of the soil castings. Erodible loose soil cast to the surface by burrowing animals could contribute to accelerated erosion of the fine-soil surface layer. 
- Wind and water erosion -- the removal of the surface soils at a waste site due to erosive forces. Erosion-related problems could provide a direct pathway for contaminant transport if the erosive forces are strong enough to remove the surface soils and expose the buried wastes to the accessible environment. A more probable scenario is for wind and water erosion to reduce the thickness of soils overlying a waste zone such that another transport pathway (i.e., water infiltration) becomes a more serious concern.

- Gaseous release -- the diffusion of noxious gases from the waste zone to the accessible environment.

Engineered barriers have been proposed to protect wastes disposed of in place from the transport pathways identified above (Figure 4-2). The protective barrier is a cover system that is a composite of layered rock (riprap) and suil materials. An integral part of the layering sequence is a coarsetextured layer thai creates a capillary break. The capillary forces of the larger rock pores are weak compared to the finer soils, thereby resulting in a reduction of water infiltration (DOE 1987).

The capillary break concept is employed in the prototype barrier design. A layer of coarse material is placed directly below finer-textured soil. Figure 4-3 illustrates the multilayer sequence of the prototype barrier. Each of these layers serves a distinct purpose. The fine-soil layer acts as a medium in which moisture is stored until the processes of evaporation and plar.t transpiration can recycle any excess water back to the atmosphere. The fine-soil layer also provides the medium for establishing plants that are necessary for transpiration to take place. The gravel admix recluces erosion due to wind. The coarser materials that are placed directly below the finesoil layers prevent the finer soils from filtering into the coarser materials and creates a capillary break that inhibits the downward percolation of water through the barrier. The basdlt riprap sequence controls biointrusion by discouraging burrowing animals and creating a low moisture layer to prevent root penetration. A low-permeability asphalt layer, placed in the barrier profile below the capillary break and the biointrusion layers, will also be used in the protective barriers. The purpose of the low-permeability layer is to (1) divert any percolating water that gets through the capillary break away from the waste zone, and (2) limit the upward movement of noxious gases from the waste zone.

\subsection{TREATABILITY TEST PLAN}

In general, the prototype barrier treatability study will be conducted in two phases. Phase I will concentrate on the design and construction of the prototype barrier and will conclude with the construction of the prototype barrier and issuance of the constructability report, which will document construction sequences and associated costs. Phase II will be initiated at the completion of prototype barrier construction and involves a 3-yr testing and monitoring program. Annual status reports will be prepared to document prototype barrier performance. 
DOE/RL-93-27, Rev. 0

Table 3-1. Potential ARAR To Be Considered (TBC). (Page 1 of 2)

\begin{tabular}{l|l}
\hline Regulation & Citation \\
\hline
\end{tabular}

FEDERAL

\begin{tabular}{|c|c|}
\hline $\begin{array}{l}\text { Atomic Energy Act of } 1954 \text {, as anended } \\
\text { " Radiation Protection Standards } \\
\text { - Nuclear Regulatory Commission Standards for Protection Against } \\
\text { Radiation } \\
\text { - Licensing Requirements for Land Disposal of Radiosctive Waste }\end{array}$ & $\begin{array}{l}42 \text { U.S.C. } 2011 \text { et seq. } \\
40 \text { CFR Part } 191 \\
10 \text { CFR Part } 20 \\
10 \text { CFR Part } 61\end{array}$ \\
\hline $\begin{array}{l}\text { Clean Air Act, as anended } \\
\text { - Air Standards for Particulates } \\
\text { - National Emissions Standards for Hazardous Air Pollutants }\end{array}$ & $\begin{array}{l}42 \text { U.S.C. } 7401 \text { et seq. } \\
40 \text { CFR } 50.6 \\
40 \text { CFR Part } 61\end{array}$ \\
\hline $\begin{array}{l}\text { Federal Water Pollution Control Act, as anended by the Clean Water Act } \\
\text { of } 1977 \\
\text { - L ignation of Hazardous Substances } \\
\text { - Determination of Reportable Quantities for Hazardous Substances } \\
\text { - National Pollutant Discharge Elimination System }\end{array}$ & $\begin{array}{l}33 \text { U.S.C. } 1251 \text { et seq. } \\
40 \text { CFR Part } 116 \\
40 \text { CFR Part } 117 \\
40 \text { CFR Part } 122\end{array}$ \\
\hline $\begin{array}{l}\text { Safe Drinking Water Act } \\
\text { - National Primary Drinking Water Regulations } \\
\text { - National Secondary Drinking Water Regulations }\end{array}$ & $\begin{array}{l}42 \text { U.S.C. } 300 f \text { et seq. } \\
40 \text { CFR Part } 141 \\
40 \text { CFR Part } 143\end{array}$ \\
\hline $\begin{array}{l}\text { Sol id Waste Disposal Act, as anended by RCRA } \\
\text { - Criteria for Classification of Solid Waste Disposal Facilities } \\
\text { and Practices } \\
\text { - Groundwater Protection Standards } \\
\text { " Land Disposal Restrictions } \\
\text { - Standards Applicable to Generators of Hazardous Haste } \\
\text { - Standards for Owners and Operators of Hazardous Heste Treatment, } \\
\text { Storage, and Disposal Facilities }\end{array}$ & $\begin{array}{l}42 \text { U.S.C. } 6901 \text { et seq. } \\
40 \text { CFR } 257.3-4 \\
40 \text { CFR } 264.92 \\
40 \text { CFR Part } 268 \\
40 \text { CFR Part } 262 \\
40 \text { CFR Part } 264\end{array}$ \\
\hline $\begin{array}{l}\text { U.S. Department of Energy Orders } \\
\text { - Radiation Protection of the Public and the Enviromment } \\
\text { - Discharge of Treatment System Effluent } \\
\text { - Radiation Protection of Occupational Horkers } \\
\text { - Safety Requirements for the Packaging of Fissile and Other } \\
\text { Radioactive Materials } \\
\text { - Radioactive Waste Management }\end{array}$ & $\begin{array}{l}\text { DOE } 5400.1, \text { DOE } 5400.5 \\
\text { DOE } 5400 . x y \\
\text { DOE } 5480.11 \\
\text { DOE } 5480.3, \text { SeC. } 7.8 \\
\text { DOE } 5820.2 \mathrm{~A}\end{array}$ \\
\hline Archaeological and Historical Preservation Act of 1974 & 16 U.S.C. 469 \\
\hline $\begin{array}{l}\text { Endangered Species Act of } 1973 \\
\text { - Fish and Wildlife Services List of Endengered and Threatened } \\
\text { Wildlife and Plants }\end{array}$ & $\begin{array}{l}16 \text { U.S.C. } 1531 \text { et seq, } 50 \text { CFR } \\
\text { Parts 17, 222, } \\
225,226,227,402,424\end{array}$ \\
\hline Historic Sites, Buildings, and Antiquities Act & U.S.C. 461 \\
\hline National Historic Preservation Act of 1966 , as amended & 16 U.S.C. 470 et seq. \\
\hline
\end{tabular}


Table 3-1. Potential ARAR To Be Considered (TBC). (Page 2 of 2)

\begin{tabular}{|c|c|}
\hline \multicolumn{2}{|l|}{ STATE/COUNTY } \\
\hline Department of Social and Health Services (Drinking Water) & 43.20A RCL \\
\hline $\begin{array}{l}\text { Model Toxics Control Act } \\
\text { - Groundwater Cleanup Standards } \\
\text { - Selection of Cleanup Actions } \\
\text { - Cleanup Actions } \\
\text { - Institutional Controls }\end{array}$ & $\begin{array}{l}\text { 70.1050 RCW } \\
\text { WAC } 173-340-720 \\
\text { WAC } 173-340-360 \\
\text { WAC } 173-340-400 \\
\text { WAC } 173-340-440\end{array}$ \\
\hline $\begin{array}{l}\text { Sol id Waste Management Recovery and Recycling Act } \\
\text { - Landfill ing Standard́s } \\
\text { - Onsite Containerized Storage, Collection, and Transportation } \\
\text { Standards }\end{array}$ & $\begin{array}{l}70.95 \text { RCW } \\
\text { HAC } 173-304-460 \\
\text { WAC } 173-304-200\end{array}$ \\
\hline $\begin{array}{l}\text { Water Pollution Control } \\
\text { - Water Criteria Classes } \\
\text { - Toxic Substances }\end{array}$ & $\begin{array}{l}90.48 \text { RCW } \\
\text { WAC } 173-201-045 \\
\text { WAC } 173-201-047\end{array}$ \\
\hline $\begin{array}{l}\text { Department of Ecology } \\
\text { - Standards for Maximum Emissions } \\
\text { - New and Modified Emissions Units }\end{array}$ & $\begin{array}{l}43.21 A \text { RCW } \\
\text { WAC } 173-400-040 \\
\text { WAC } 173-480-060\end{array}$ \\
\hline Regulation of Public Groundwater & $90.44 \mathrm{RCH}$ \\
\hline $\begin{array}{l}\text { Habitat Buffer Zone for Bald Eagle Rules } \\
\text { - Bald Eagle Protection Rules }\end{array}$ & $\begin{array}{l}\text { RCW } 77.12 .655 \\
\text { WAC } 232-12-292\end{array}$ \\
\hline $\begin{array}{l}\text { Regulating the Taking and Processing of Game } \\
\text { - Endangered, Threatened, or Sensitive Wild ife Species } \\
\text { Classification }\end{array}$ & $\begin{array}{l}\text { RCW } 77.12 .040 \\
\text { HAC } 232-12-297\end{array}$ \\
\hline Benton-Franklin-Walla Walla Counties Air Pollution Control Authority & General Regulation $80-7$ \\
\hline Residual Radioactive Material as Surface Contanination & U.S. NRC Regulatory Guide 1.86 \\
\hline Department of Ecology Liquid Effluent Consent Order & DE $91 \mathrm{NM}-177$ \\
\hline Floodplains/Wet lands Enviromental Review & 10 CFR Part 1022 \\
\hline Protection and Enhancement of the Cultural Emvirorment & Executive Order 11593 \\
\hline
\end{tabular}


Table 3-2. Potential ARAR for Covers.

\begin{tabular}{|c|c|}
\hline Regulation & Citation \\
\hline \multicolumn{2}{|l|}{ FEDERAL } \\
\hline $\begin{array}{l}\text { Transuranic Waste } \\
\text { - Containment Requirements } \\
\text { - Individual Protection Requirement } \\
\text { - Ground Water Protection Requirenent }\end{array}$ & $\begin{array}{l}40 \text { CFR Part } 191.13 \\
40 \text { CFR Part } 191.15 \\
40 \text { CFR Part } 199.16\end{array}$ \\
\hline $\begin{array}{l}\text { Low-Level Waste } \\
\text { - Protection of Individual from Inadvertent Intrusion } \\
\text { - Waste Classification } \\
\text { - Disposal Site Design for Land Disposal } \\
\text { - Land Disposal Facility Operation and Disposal site Closure }\end{array}$ & $\begin{array}{l}10 \text { CFR Part } 61.42 \\
10 \text { CFR Part } 61.55 \\
10 \text { CFR Part } 61.51 \\
10 \text { CFR Part } 61.52\end{array}$ \\
\hline $\begin{array}{l}\text { Hazardous Waste } \\
\text { - Closure Performance Standards } \\
\text { - Closure and Post-Closure Care }\end{array}$ & $\begin{array}{l}40 \text { CFR Part } 264.111 \\
40 \text { CFR Part } 264.310\end{array}$ \\
\hline $\begin{array}{l}\text { Sol id Waste } \\
\text { - Cover Material } \\
\text { - Compaction } \\
\text { - Closure Criteria }\end{array}$ & $\begin{array}{l}40 \text { CFR Part } 241.209 \\
40 \text { CFR Part } 241.210 \\
40 \text { CFR Part } 258.60\end{array}$ \\
\hline $\begin{array}{l}\text { Inert Waste/Demolition Waste } \\
\text { - Standard for Inactive Haste Disposal Sites for Asbestos Mills and } \\
\text { Manufacturing and Fabricating Operations }\end{array}$ & 40 CFR Part 61.151 \\
\hline \multicolumn{2}{|l|}{ STATE } \\
\hline $\begin{array}{l}\text { Dangerous Waste } \\
\text { - Closure and Post-closure } \\
\text { - Landfills }\end{array}$ & $\begin{array}{l}\text { WAC } 173-303-610 \\
\text { WAC } 173-303-665\end{array}$ \\
\hline $\begin{array}{l}\text { Sol id Waste } \\
\text { - General Closure and Post-Closure Requirements } \\
\text { - Landfill Standards }\end{array}$ & $\begin{array}{l}\text { WAC } 173-304-407 \\
\text { HAC } 173-304-460\end{array}$ \\
\hline $\begin{array}{l}\text { Inert Waste/Demolition Waste } \\
- \text { Inert Waste and Demolition Waste Landfilling Facility }\end{array}$ & WAC $173-304-461$ \\
\hline
\end{tabular}


DOE/RL-93-27, Rev. 0

Figure 4-1. Potential Problems of the Current Waste Management Situation.
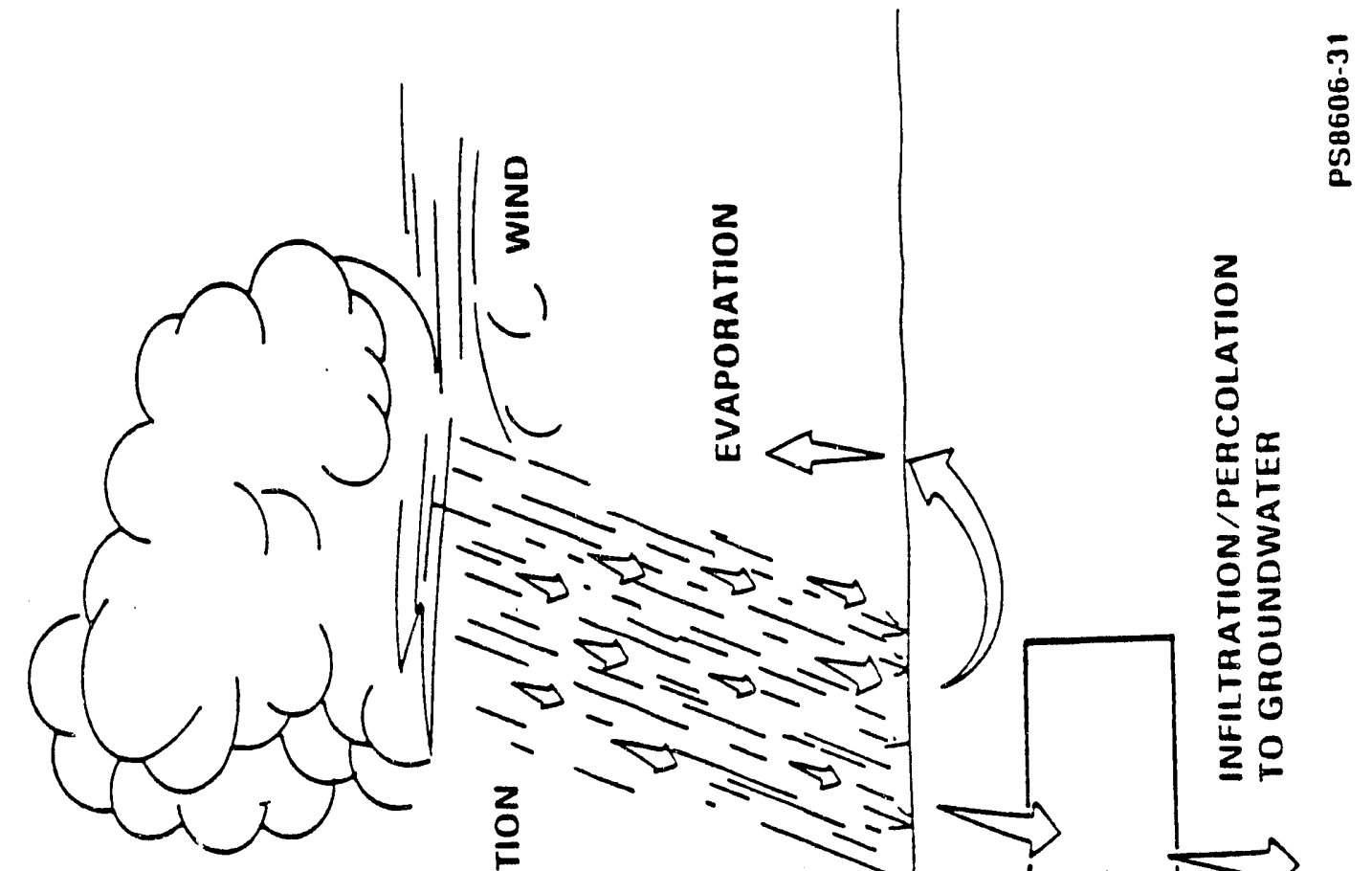

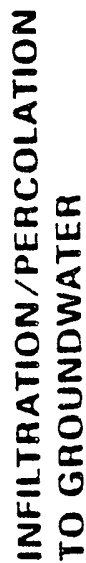
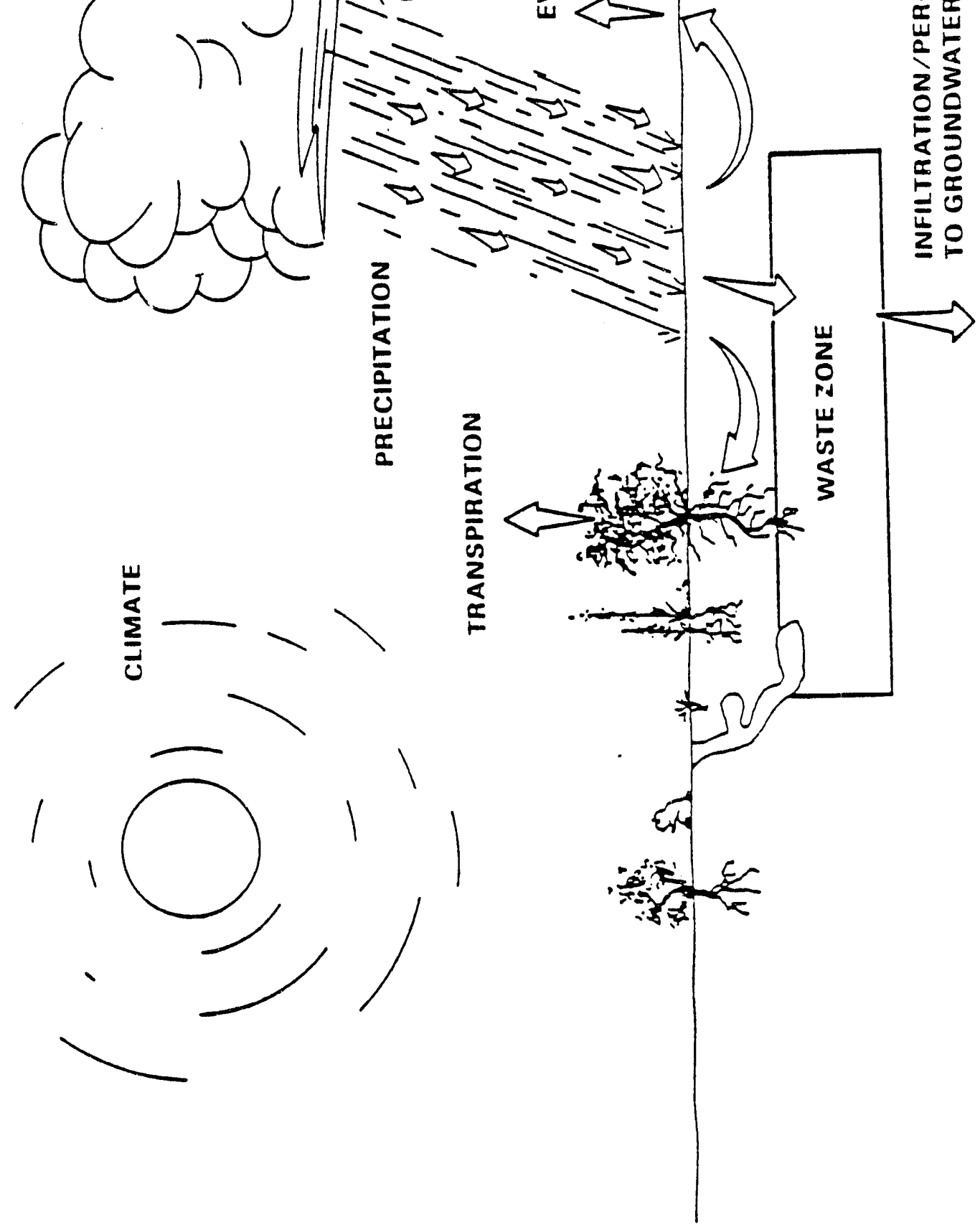
DOE/RL-93-27, Rev. 0

Figure 4-2. Functional Performance of Barriers.

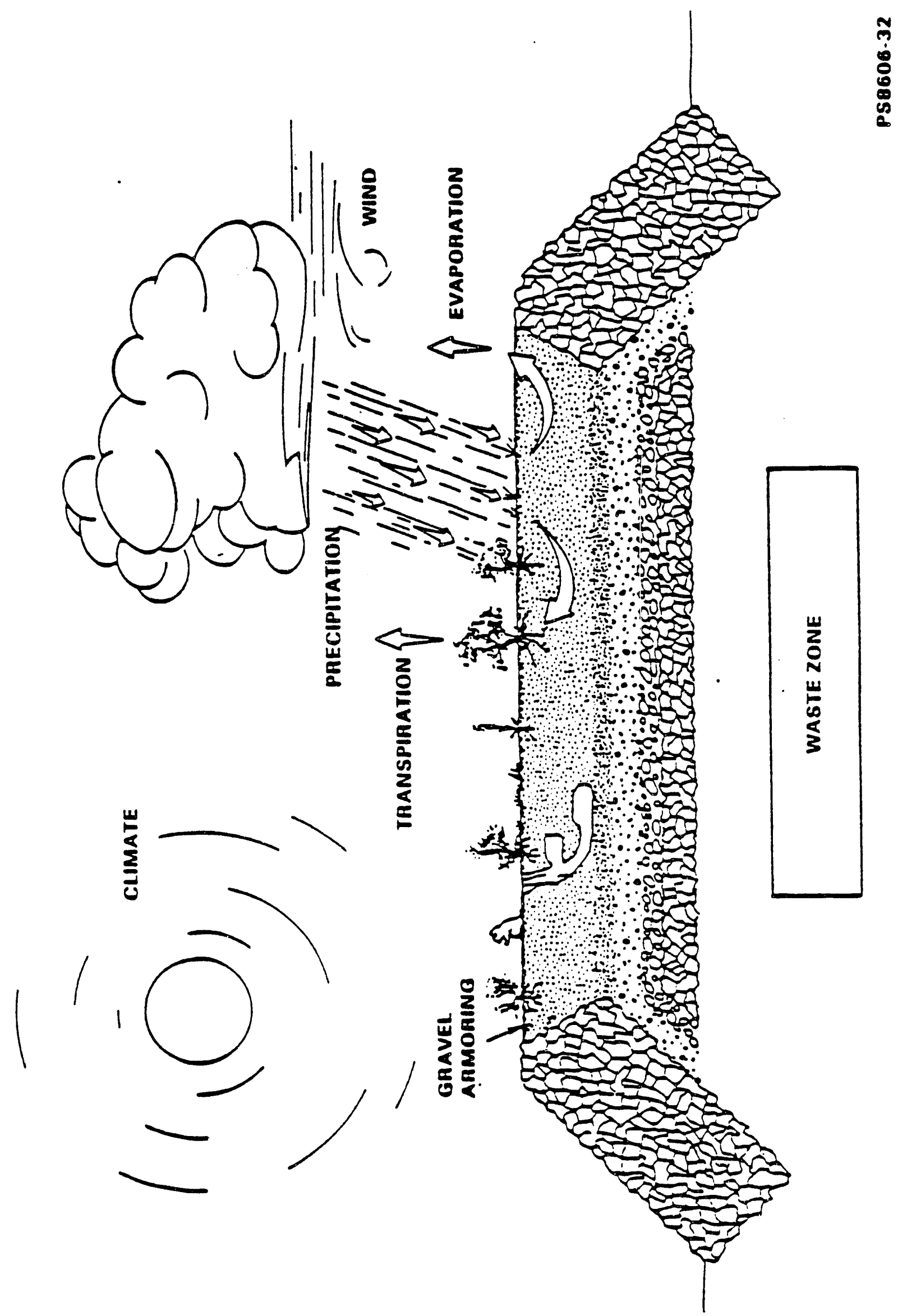


Figure 4-3. Typical Barrier Cross Section.

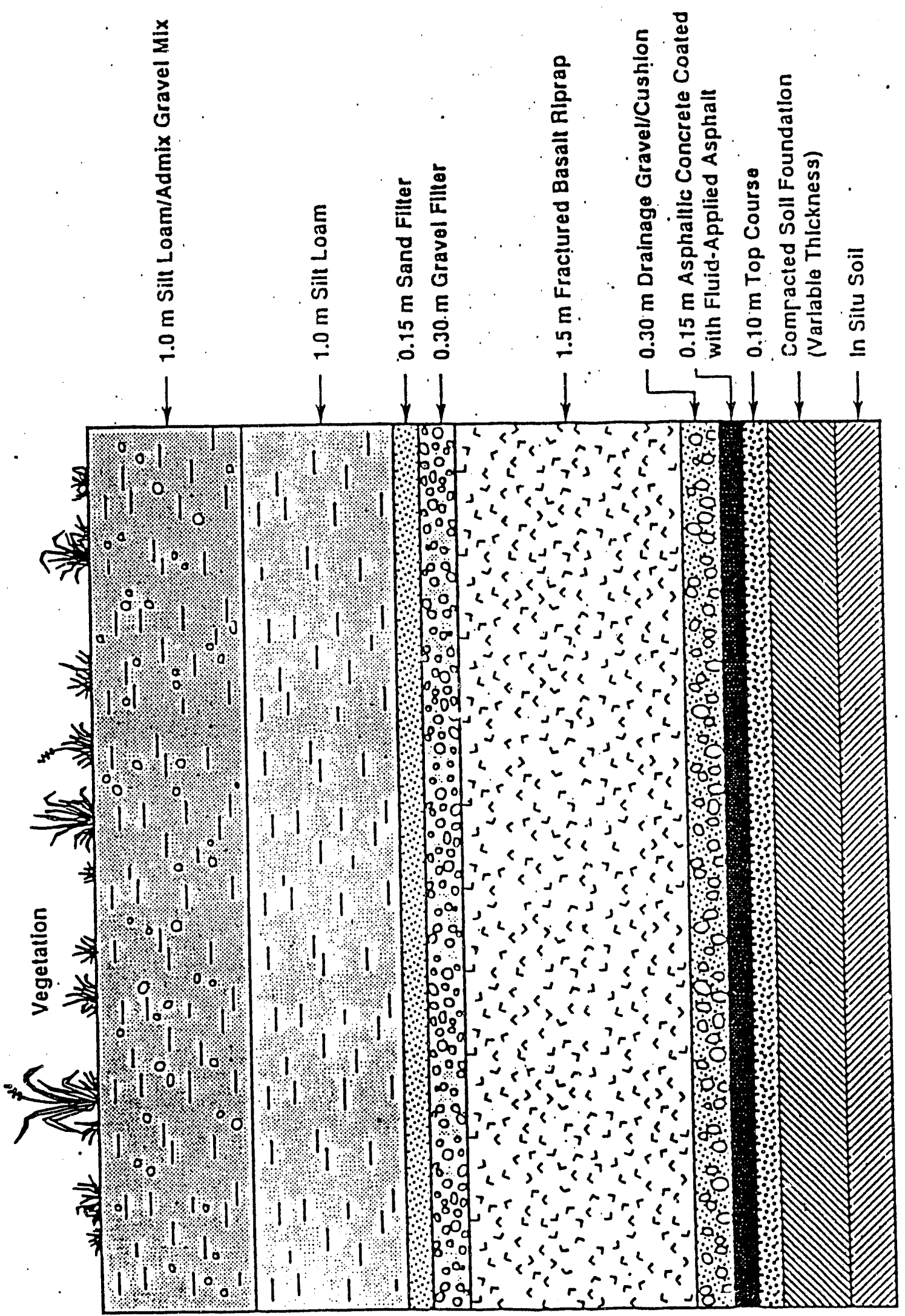




\subsubsection{Treatability Test Plan Phase I: Design and Construction}

Phase I consists of design and construction of the prototype barrier over the 216-B-57 Crib. Detailed cost data will be collected during the construction phase. As previously mentioned in Section 1.2, 200-BP-1 operable unit is ideal for establishing these baseline cost estimates. In addition, data will be collected on the impacts of construction practices and equipment on overall barrier performance. Insights into this area will help identify and implement appropriate quality control (QC) during actual barrier construction to assure that the barrier performs as designed.

\subsubsection{Treatability Test Plan Phase II: Testing and Monitoring}

Once constructed, it is expected to take approximately 1 yr for the prototype barrier to stabilize. The prototype barrier will be evaluated for two complete growing cycles to determine its performance over a range of conditions representative of those expected to be experienced during the design life of a permanent isolation barrier. Thus, 3 yr of testing and monitoring will be required. A number of tests and experiments are planned to be conducted on the prototype barrier to assess its performance, $v$ is a $v$ is water infiltration, biointrusion, erosion, and physical stability. Because only a finite amount of time exists to test a prototype barrier that is intended to function for at least 1,000 yr, the testing program has been designed to "stress" the prototype so that barrier performance can be determined within a reasonable time frame. These stress tests include such things as adding supplemental amounts of water to the surface and side slopes of the prototype to simulate a change in climate to wetter conditions.

The DQO for testing and monitoring the performance of a prototype barrier are discussed in Section 2.1. Details on the testing and monitoring program are provided by Gee et al. (1993).

4.2.2.1 Water Infiltration Tests. Concentrations of contaminants in the vadose zone underlying the 216-B-57 Crib are highest on the south end, reducing to below detection at the north end (DOE 1993). Precipitation testing of the prototype barrier is to be performed at the less-contaminated north end of the crib.

Two major issues will be addressed in the prototype testing: (1) the effects that extreme precipitation events have on water infiltration, and (2) the effect of water infiltration on side slope stability and subsurface water content changes.

Drainage from the soil cover when exposed to either ambient or elevated precipitation is anticipated to be near zero. However, a sizable amount of drainage from the rock side slopes is anticipated.

4.2.2.2 Water Erosion Tests. The objective of this monitoring is to develop a baseline database for the top surface soil/admix system with respect to erosion and soil surface "aging" under natural conditions. The data and information collected will be combined with results from an offsite test plot (located at the McGee Ranch) to identify design problems that develop over the ife of the prototype barrier, to finalize top surface design criteria, and to provide supporting data and information to other tasks. The database will 
include measurements of the changes in engineering and soil properties at the surface, documenting erosional patterns, the establishment of vegetation as it affects erosion, and disturbance by animals.

4.2.2.3 Wind Erosion Tests. Wind erosion testing will be conducted to determine impacts to actual waste site barriers. Testing includes: (1) monitor the surface layer after construction and as it ages under exposure to natural conditions; (2) measure actual rates of surface deflation or inflation; (3) obtain micro-meteorological information about erosive or shear stresses that impact the barrier (including the influence of the pile height and edge design on wind patterns); (4) obtain information about abrasive sand particle scouring (saltation); (5) create a sand dune and monitor the impact on surface erosion, plant community viability, and soil reservoir water balance; and (6) study erosive impacts after an artificial wildfire removes all surface vegetation.

4.2.2.4 Biointrusion Tests. The main objectives of the biointrusion tests are to: (1) evaluate the extent to which plant roots exploit the depth of the fine-soil layer under actual barrier construction conditions; (2) to determine whether the roots of established vegetation penetrate the various biointrusion control layers; and (3) document the extent of animal intrusion.

4.2.2.5 Asphalt Testing: RCRA Equivalence and Other Considerations. One of the major DQO of the testing and monitoring activities described here is to provide data that will ensure that cover design(s) used at the Hanford Site meet or exceed regulatory requirements. Standard cover designs for waste sites generally must comply with RCRA. The RCRA cover design has a specified configuration to protect human health and environment by minimizing water infiltration, etc. It generally consists of a clay layer and an impermeable plastic geomembrane, buried under a soil cover and a lateral drainage layer (used to divert excess water away from the waste site). The clay layer is compacted and has a permeability specification that is equivalent to a saturated hydraulic conductivity of about $30 \mathrm{~mm} / \mathrm{yr}$. Unspecified but lower permeability is expected with the composite liner (clay and plastic). Other cover designs (Hanford barrier) may be proposed for consideration consisting of such things as asphalt layers, etc. However, such designs for RCRA sites must demonstrate effectiveness in protecting human health and environment including low water permeability prior to gaining regulatory approval. RCRA equivalent performance is expected of the prototype barrier and will be evaluated under this treatability test plan.

In the prototype barrier, a composite asphalt layer is substituted for the clay and plastic composite of the RCRA barrier. Briefly, the asphalt composite consists of two layers of asphaltic concrete mix topped with a layer of hot-applied rubberized asphalt (polymer modified asphalt-geotextile). It is expected that the composite asphalt layer will exceed the clay-plastic composite in performance and durability, and this will be verified through prototype barrier testing activities. Field tests will include permeability as well as stress-strain testing. 


\subsection{RESIDUALS MANAGEMENT}

Due to nearby active facilities, surface contamination had occurred at the 200-BP-1 operable unit (DOE-RL 1990). As part of the Phase I RI activities, all surface contamination areas have been stabilized. As a precautionary measure, the prototype barrier will be surveyed by Health Physics

Technicians (HPT) to assure that the surface of the prototype barrier is contaminant-free prior to conducting prototype barrier testing and monitoring activities at regular intervals thereafter. Any contaminated soils detected will be removed and disposed of in accordance with provisions of the 200-BP-1 operable unit work plan (DOE-RL 1990).

In the unlikely event that the HPT fail to detect surface contamination ard runoff water from prototype barrier testing becomes contaminated, the contaminated water will be managed in a manner that is protective of human health and the environment. The prototype barrier has been designed with collection systems to channel side slope runoff and infiltrating waters to a collection point where the volume can be determined. This water holding system will enable determination of the level of water contamination. If contaminant-free, the water will be discharged to the soil column in a manner that will not interact with any subsurface contamination contained in the 200-BP-I operable unit. If contaminated, precipitation testing will be terminated until the source of the contamination is located.

\subsection{REPORTS}

Several reports will be prepared as a result of prototype barrier construction and subsequent testing and monitoring activities. These reports include a construction report and annual treatability test reports.

\subsection{CONSTRUCTION REPORT}

It is critical that construction is completed in accordance with the latest version of approved plans and specifications to ensure proper performance of the prototype barrier system. This necessitates the proper selection and use of construction forces, construction methods, and equipment. Construction $Q C$ will play an important role in assuring that the prototype barrier system is constructed as designed. In addition to the prototype barrier design media, construction specification, and QC plan, a construction repart will be prepared to document the process used in constructing the prototype barrier in accordance with its design. The construction report may include, but not be limited to, discussions of the following:

- overall design and placement of the prototype barrier

- site preparation

- compaction of foundation layer

- design and placement of low permeability component, e.g., asphait) 
- placement of basaltic materials within the barrier profile and on the side slopes

- design and placement of graded filters

- mixing and placement of fine topsoil layers

- runoff and runon design controls

- overall construction QC (including discussions of test pads, as appropriate)

- construction costs, on a unit basis, for each of the construction materials and activities

- overall construction schedule and timing.

\subsection{TESTING AND MONITORING REPORTS}

In addition to the prototype barrier testing and monitoring plan (Gee et a1. 1993), treatability study reports will be prepared annually to document the performance of the prototype barrier system. These treatability study reports may include, but not be limited to, discussions of the following:

- experimental design

- experimental results

- data evaluation and interpretation

- overall prototype barrier performance

- QC

- data management and archiving

- recommendations for future tests and full-scale implementation.

As previously stated in Section 1.2, the results from prototype barrier testing and monitoring will supplement roughly 60 technical publications describing testing results to date on individual components of the protective barrier (Appendix A).

\subsection{PROJECT MANAGEMENT}

The design, construction, and testing of the prototype protective barrier under this treatability study has multiple onsite contractor interfaces and responsibilities. Figures 7-1, 7-2, and 7-3 identify the organizational lines of communication as they are currently envisioned.

\subsection{SCHEDULE}

The schedule of each of the two phases of the prototype barrier project (design/construction and testing) at the 200-BP-1 operable unit site are identified in this section. 
The design of the prototype barrier over the 216-B-57 Crib is scheduled to be completed in FY 1993. Construction of the prototype barrier is planned to be initiated during FY 1993 and completed during FY 1994. A detailed schedule of the design and construction phases is provided in Figure 8-1. The testing and monitoring of the prototype barrier's performance will require three years following the construction of the prototype barrier. The tasks associated with the testing and monitoring phase are described in detail in the document entitled, Testing and Monitoring Plan for the Permanent Isolation Surface Barrier Prototype (Gee et a1. 1993). 
DOE/RL-93-27, Rev. 0

Figure 7-1. Lines of Communication During the Design Phase.

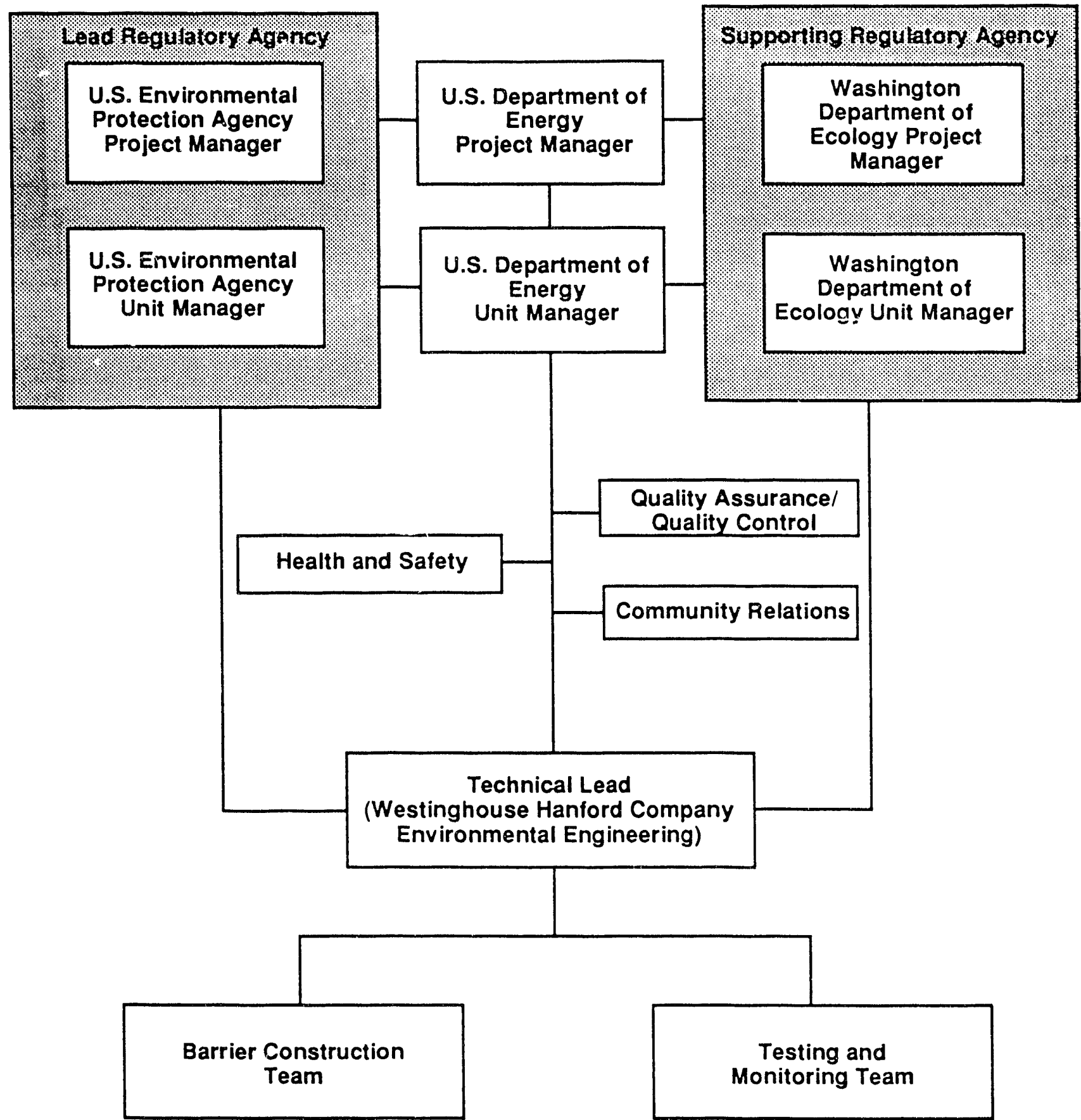


DOE/RL-93-27, Rev. 0

Figure 7-2. Lines of Communication During the Construction Phase.
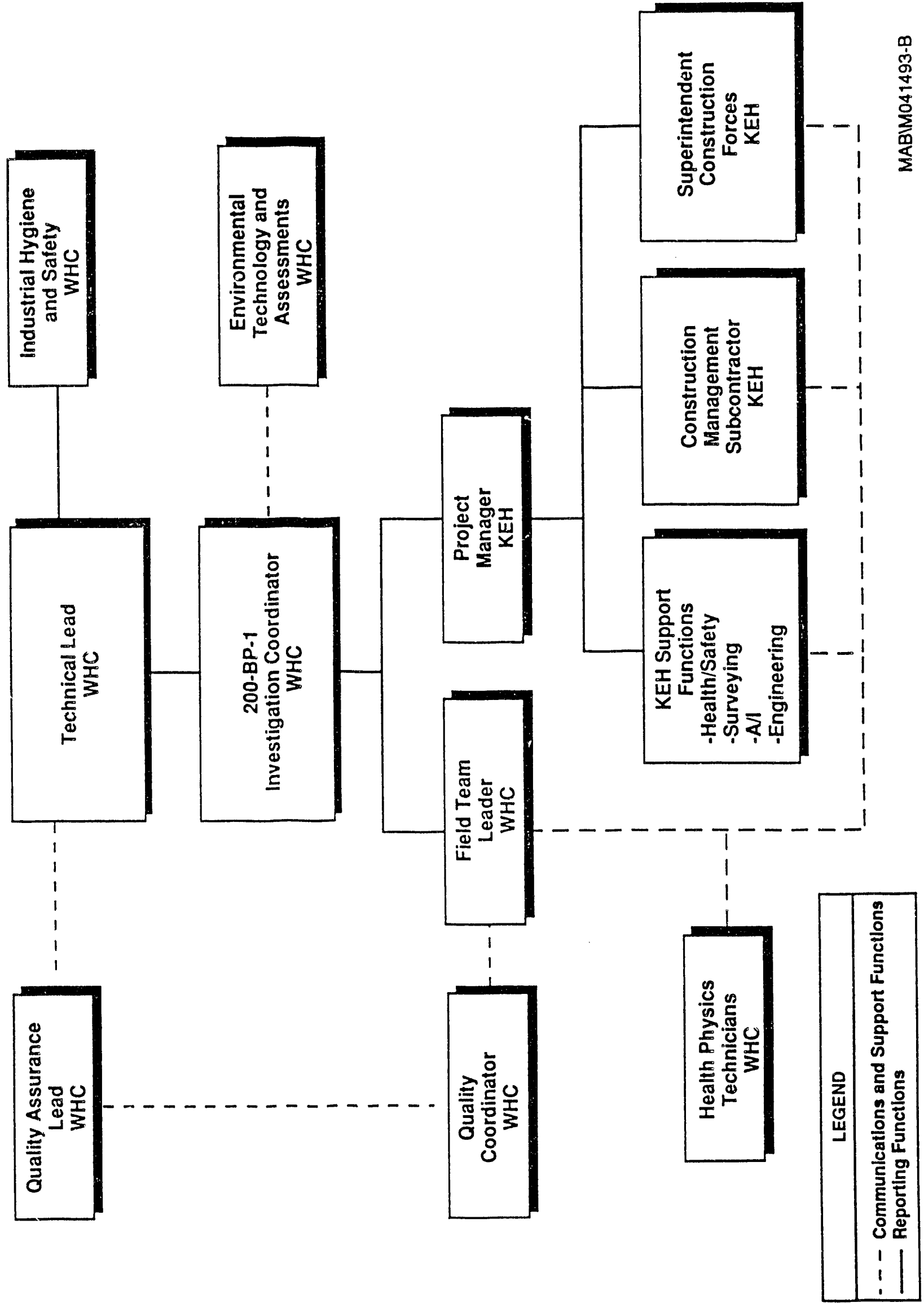
Figure 7-3. Lines of Communication During the Testing and Monitoring Phase.

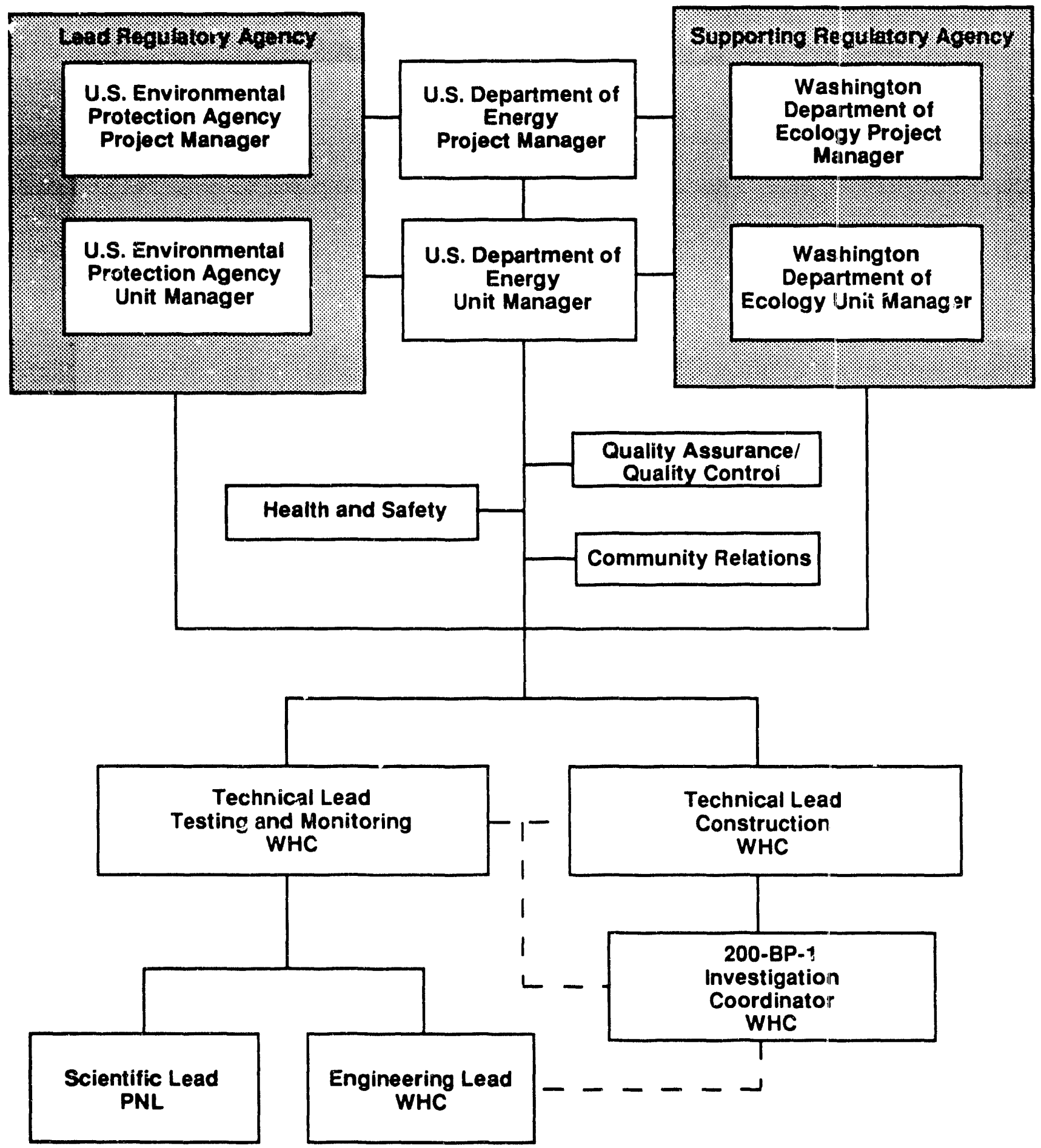


DOE/RL-93-27, Rev. 0

Figure 8-1. Design and Construction Schedule. (Page 1 of 2)

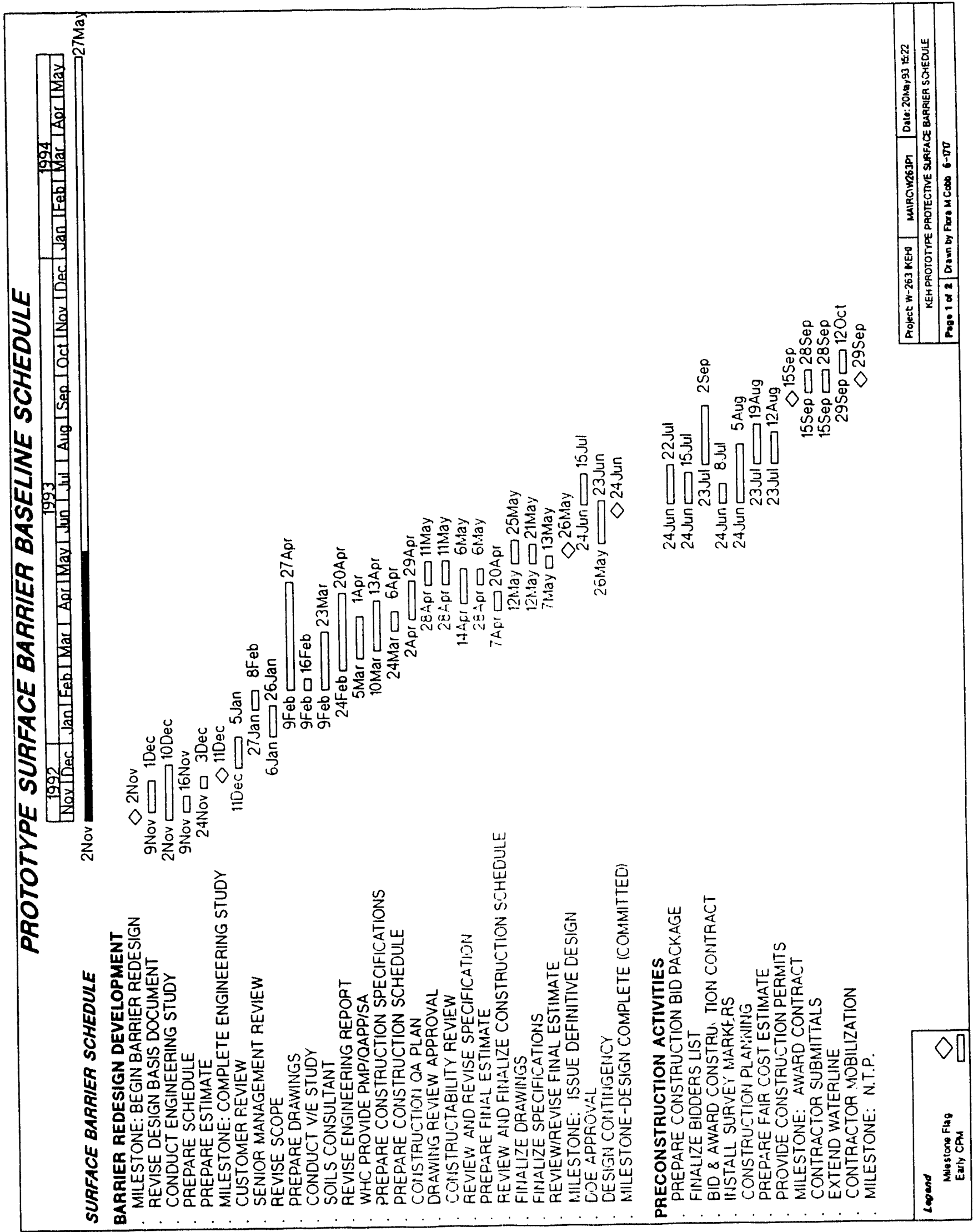


Figure 8-1. Design and Construction Schedule. (Page 2 of 2)

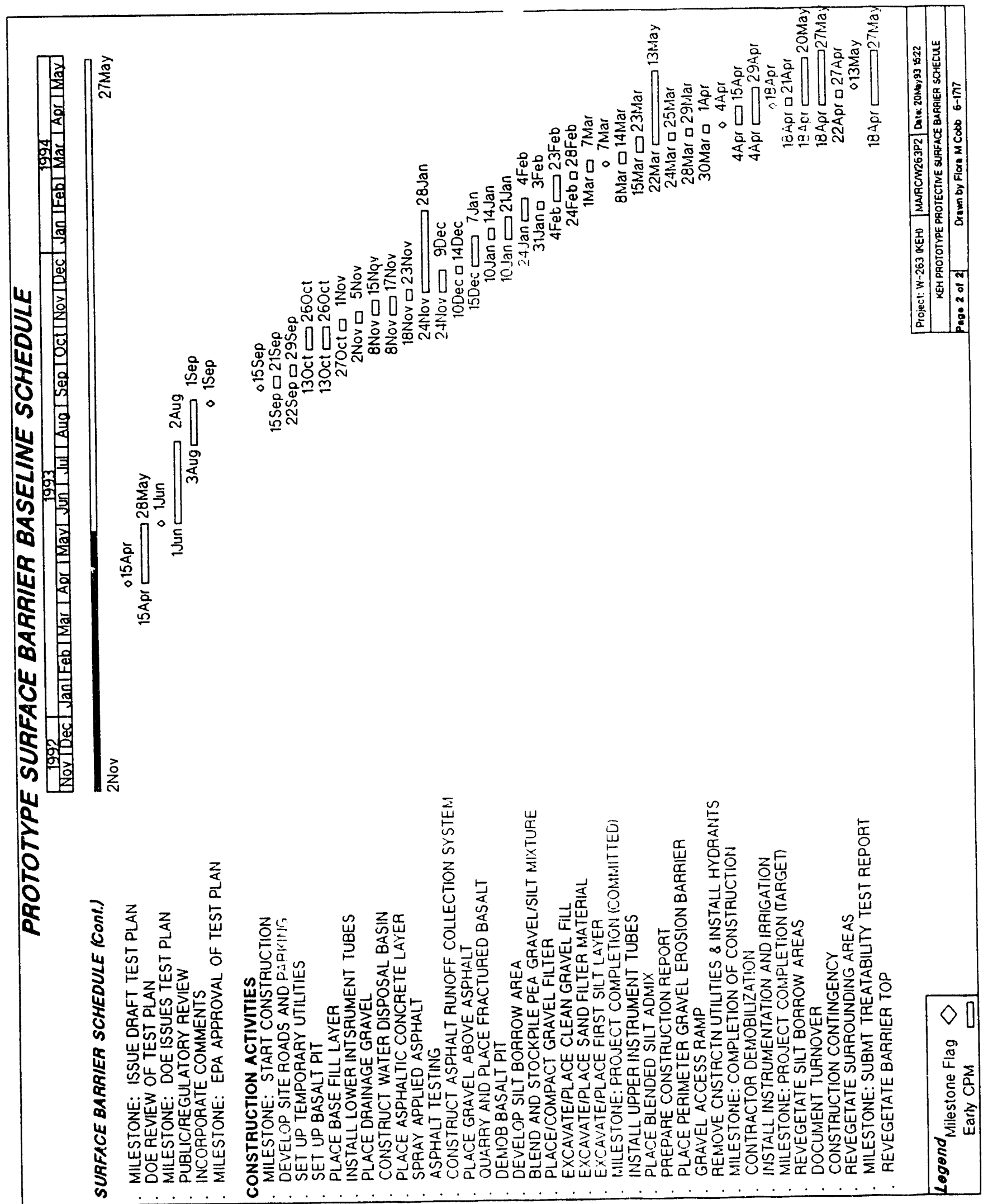




\subsection{REFERENCES}

$\mathrm{DOE} / \mathrm{RL}, 1987$, Final Environmental Imapact Statement, Disposal of Hanford Defense High-Leve I, Transuranic and Tank Wastes, DOE/EIS-0113, Vol. 3, U.S. Department of Energy, Richland Operations, Richland, Washington.

DOE-RL, 1990, Remedial Investigation/Feasibility Study Work Plan for the 200-BP-1 Operable Unit, Hanford Site, Richland, Washington, DOE/RL88-32, Rev. 1. U.S. Department of Energy, Richland Operations, Richland, Washington.

DOE-RL, 1993a, Phase I Remedial Investigation Report for 200-BP-1 Operable Unit, DOE/RL-92-70, Draft A, 2 Vols., U.S. Department of Energy, Richland Field Office, Richland, Washington.

DOE-RL, 1993b, 100-HR-3 Groundwater Treatability Test Plan, DOE/RL 92-73, Rev. O, U.S. Department of Energy, Richland Field Office, Richland, Washington.

DOE-RL, 1992, Hanford Site Waste Management Units Report, DOE/RL 88-30, Rev. 2, U.S. Department of Energy, Richland Operations, Richland, Washington.

EPA, 1985, Covers for Uncontrolled Hazardous Waste Sites, EPA/540/2-85/002, U.S. Environmental Protection Agency, Washington, D.C.

EPA, 1992, Guide for Conducting Treatability Studies Under CERCLA, EPA/540/ R-92/071a, U.S. Environmental Protection Agency, Washington, D.C.

Gee, G. W., L. L. Cadwel1, H. D. Freeman, M. W. Ligotke, S. O. Link, R. A. Romine, W. H. Walters Jr., and $N$. R. Wing, 1993, Testing and Monitoring PIan for the Permanent Isolation Surface Barrier Prototype, PNL-8391, Pacific Northwest Laboratory, Richland, Washington. 


\section{APPENDIX A \\ PUBLISHED PERMANENT ISOLATION BARRIER DOCUMENTS \\ (As of May 27, 1993)}

1. Phillips, S. J., M. R. Adams, T. W. Gilbert, C. C. Meinhardt,

R. M. Mitchell, and W. J. Waugh, 1985, Engineered Barrier Test Facility Status Report: 1984, RHO-WM-SR-3P, Rockwe11 Hanford Operations, Richland, Washington.

2. Phillips, S. J., T. W. Gilbert, and M. R. Adams, 1985, Preliminary Engineering Specifications for a Test Demonstration Multilayer Protective Barrier Cover System, RHO-WM-EV-8P, Rockwe11 Hanford Operations, Richiand, Washington.

3. Fayer, M. J., W. Conbere, P. R. Heller, and G. W. Gee, 1985, Model Assessment of Protective Barrier Designs, PNL-5604, Pacific Northwest Laboratory, Richland, Washington.

4. Myers, D. R., 1985, Disposal Materials Study, RHO-WP-EV-12P, Rockwel1 Hanford Operations, Richland, Washington.

5. Adams, M. R., and M. F. Kaplan, 1986, "Marker Development for Hanford Waste Site Disposal", in Waste Management '86, (Vol. 1), R. G. Post (ed.),pp. 425-431, University of Arizona, College of Engineering and Mines, Tucson, Arizona.

6. Phillips, S. J., and J. N. Hartley, 1986, "Protective Barrier Systems for Final Disposal of Hanford Waste Sites," in Waste Management '86, (Vol. 1), pp. 433-437, R. G. Post (ed.), University of Arizona, College of Engineering and Mines, Tucson, Arizona.

7. Kaplan, M. F., and M. R. Adams, 1986, "Using the Past to Protect the Future: Marking Nuclear Waste Disposal Sites," Archeology 39(5):51-54.

8. Adams, M. R. and N. R. Wing, 1986, Protective Barrier and Warning Marker System Development Plan, RHO-RE-PL-35P, Rockwell Hanford Operations, Richland, Washington.

9. Fayer, M. J., 1987, Model Assessment of Protective Barrier Designs: Part II, PNL-6297, Pacific Northwest Laboratory, Richland, Washington.

10. Last, G. V., M. A. Glennon, M. A. Young, and G. W. Gee, 1987, Protective Barrier Materials Analysis: Fine Soil Site Characterization, PNL-6314, Pacific Northwest Laboratory, Richland, Washington.

11. Gee, G. W., 1987, "Preliminary Analys is of the Performance of the Protective Barrier and Marker System," Appendix $M$ in Final Environmental Impact Statement, Disposal of Hanford Defense High-Level, Iransuranic and Tank Wastes, DOE/EIS-0113, U.S. Department of Energy Richland Operations Office, Richland, Washington. 
12. Kirkham, R. R., G. W. Gee, and J. L. Downs, 1987, Field Lysimeter Test Facility for Protective Barriers: Experimental Plan, PNL-6351, Pacific Northwest Laboratory, Richland, Washington.

13. Waugh, W. J., and S. 0. Link, 1988, Barrier Erosion Control Test Plan: Gravel Mulch, Vegetation, and Soil Water Interactions, WHC-EP-0067, Westinghouse Hanford Company, Richland, Washington.

14. Wing, N. R., M. D. Campbel1, J. L. Downs, G. W. Gee, R. R. Kirkham, and S. J. Phillips, 1988, "Protective Barrier Development: The Field Lysimeter Test Facility," in Proceedings of the International Topical Meeting on Nuclear and Hazardous Waste Management Spectrum '88, pp. 196-198, American Nuclear Society, Inc., La Grange Park, I1 1 ino is, WHC-SA-0203-FP, Westinghouse Hanford Company, Richland, Washington.

15. Phillips, S. J., M. S. Ruben, and R. R. Kirkham, 1988, "Engineered Surface Barriers for Waste Disposal Sites: Lysimeter Facility Design and Construction," in DOE Model Conference Proceedings, pp. 1229-1238, CONF-881054, 0ct. 3-7, Martin Marietta, Oak Ridge, Tennessee.

16. Ligotke, M. W., 1988, Soil Erosion Rates from Mixed Soil and Gravel Surfaces in a Wind Tunnel: A Preliminary Report, PNL-6677, Pacific Northwest Laboratory, Richland, Washington.

17. Waugh, W. J., and M. G. Foley, 1988, Protective Barrier Climate-Change Impacts: Technical Workshop Findings and Recommendations, PNL-6615, Pacific Northwest Laboratory, Richland, Washington.

18. Ligotke, M. W., 1989, Surface Stability Test Plan for Protective Barriers, PNL-6722, Pacific Northwest Laboratory, Richland, Washington.

19. Gee, G. W., R. R. Kirkham, J. L. Downs, and M. D. Campbe11, 1989, The Field Lysimeter Test Facility (FLTF) at the Hanford Site: Installation and Initial Tests, PNL-6810, Pacific Northwest Laboratory, Richland, Washington.

20. Gee, G. W., M. D. Campbe11, H. D. Freeman, and J. F. Cline, 1989, Assessment of Cover Systems at the Grand Junction, Colorado Uranium Mill Tailings Pile: 1987 Field Measurements, PNL-6762, Pacific Northwest Laboratory, Richland, Washington.

21. Petersen, K. L., 1989, The Long-Term Climate Change Assessment Task of the Hanford Site, Washington, Protective Barrier Development Program, WHC-SA-0537-FP, Westinghouse Hanford Company, Richland, Washington.

22. Cadwe11, L. L., E. L. Eberhardt, and M. A. Simmons, 1989, Animal Intrusion Studies for Protective Barriers: Status Report for FY 1988, PNL-6869, Pacific Northwest Laboratory, Richland, Washington.

23. Freeman, H. D., G. W. Gee, and J. F. Relyea, 1989, Field Study Plan for Alternate Barriers, PNL-6840, Pacific Northwest Laboratory, Richland, Washington. 
24. Freeman, H. D., and G. W. Gee, 1989, Hanford Protective Barriers Program Asphalt Barrier Studies - FY 1988, PNL-6874, Pacific Northwest Laboratory, Richland, Washington.

25. Waugh, W. J., 1989, Gravel Admix, Vegetation and Soil Water Interactions in Protective Barriers: Experimental Design, Construction and Initial Conditions, PNL-6616, Pacific Northwest Laboratory, Richland, Washington.

26. Freeman, H. D., and G. W. Gee., 1989, Hanford Protective Barriers Program: Status of Asphalt Barrier Study - FY 1989, PNL-7153, Pacific Northwest Laboratory, Richland, Washington.

27. Link, S. 0., and W. J. Waugh, 1989, Evapotranspiration Studies for Protective Barriers: Experimental Plans, PNL-6899, Pacific Northwest Laboratory, Richland, Washington.

28. Petersen, K. L., 1990, "The Long-Term Climate Change Assessment Task of the Protective Barrier Development Program for Low-Level Waste Site Remediation at the Hanford Site, Washington," in High Level Radioactive Waste Management, vol 2, pp. 1235-1239, Proceeding of an International Topical Meeting, American Nuclear Society, La Grange, Park, Ill inois, (WHC-SA-0808-FP, Westinghouse Hanford Company, Richland, Washington).

29. Fayer, M. J., 1990, Test Plan for Hydrologic Modeling of Protective Barriers, PNL-7152, Pacific Northwest Laboratory, Richland, Washington.

30. Wing, N. R., and G. W. Gee (eds), 1990, Hanford Site Protective Barrier Development Program: Fiscal Year 1989 Highlights, WHC-EP-0318, Westinghouse Hanford Company, Richland, Washington.

31. Campbe11, M. D., G. W. Gee, M. J. Kanyid, and M. L. Rockhold, 1990, Field Lysimeter Test Facility: Second Year (FY 1989) Test Results, PNL-7209, Pacific Northwest Laboratory, Richland, Washington.

32. Landeen, D. S., L. L. Cadwe11, L. E. Eberhardt, R. E. Fitzner, and M. A. Simmons, 1990, Animal Intrusion Field Test Plan, WHC-EP-0253, Westinghouse Hanford Company, Richland, Washington.

33. Link, S. 0., M. E. Thiede, R. D. Evans, J. L. Downs, and W. J. Waugh, 1990, Evapotranspiration Studies for Protective Barriers: FY 1988 Status Report, PNL-6985, Pacific Northwest Laboratory, Richland, Washington.

34. Relyea, J. F., M. R. Sackschewsky, W. J. Waugh, 1989, Small-Tube Lysimeter Facility Status Report for Fiscal Year 1989, WHC-EP-0297, Westinghouse Hanford Company, Richland, Washington.

35. Walters, W. H., K. A. Hoover, and L. L. Cadwe11, 1990, Project Test Plan for Runoff and Erosion on Fine-Soil Barrier Surfaces and Rock-Covered Side Slopes, PNL-6791, Pacific Northwest Laboratory, Richland, Washington. 
36. Hoover, K. A., L. L. Cadwel1, and W. H. Walters, 1990, Hanford Protective Barriers Program: Water Erosion Studies - FY 1989, PNL-7214, Pacific Northwest Laboratory, Richland, Washington.

37. Landeen, D. S., 1990, Animal Intrusion Status Report for Fiscal Year 1989, WHC-EP-0299, Westinghouse Hanford Company, Richland, Washington.

38. Ligotke, M. W., and D. C. Klopfer, 1990, Soil Erosion Rates from Mixed Soil and Gravel Surfaces in a Wind Tunnel, PNL-7435, Pacific Northwest Laboratory, Richland, Washington.

39. Waugh, W. J., M. E. Thiede, C. J. Kemp, L. L. Cadwe11, and S. 0. Link, 1990, Field Study of Gravel Admix, Vegetation, and Soil Water

Interactions: Protective Barrier Program Status Report - FY 1989,

PNL-7440, Pacific Northwest Laboratory, Richland, Washington.

40. Hunter, C. R., A. J. Busacca, and W. J. Waugh, 1990, A Feasibility Study of Modeling Pedogenic Carbonates in Soils and Sediments at the U.S. Department of Energy's Hanford Site, PNL-7413, Pacific Northwest Laboratory, Richland, Washington.

41. Wing, N. R. and G. W. Gee, 1990, "Protective Barrier Development: Overview," In Proceedings of the Twenty-Eighth Hanford Symposium on Health and the Environment, Environmental Monitoring, Restoration, and Assessment: What Have We Learned?, pp. 147-151, R. H. Gray (ed.), Pacific Northwest Laboratory, Richland, Washington, WHC-SA-0619-FP, Westinghouse Hanford Company, Richland, Washington.

42. Wing, N. R. and G. W. Gee, 1990, "Protective Barrier Development: Overview," in Proceedings of the International Topical Meeting on Nuclear and Hazardous Waste Management Spectrum '90, pp. 335-337, American Nuclear Society, Inc., La Grange Park, Ill inois, WHC-SA-0985-VA, Westinghouse Hanford Company, Richland, Washington.

43. Glantz, C. S., M. N. Schwartz, K. W. Burk, R. B. Kaspar, M. W. Ligotke, and D. J. Perrault, 1990, Climatological Summary of Wind and Temperature Data for the Hanford Meteorology Monitoring Network, PNL-7471, Pacific Northwest Laboratory, Richland, Washington.

44. Campbe11, M. D., and G.W. Gee, 1990, Field Lysimeter Test Facility: Protective Barrier Test Results (FY 1990, The Third Year), PNL-7558, Pacific Northwest Laboratory, Richland, Washington.

45. Sackschewsky, M. R., J. C. Chatters, S. 0. Link, and C. A. Brandt, 1991, Protective Barrier Program: Test Plan for Plant Community Dynamics, WHC-EP-0380, Westinghouse Hanford Company, Richland, Washington.

46. Nichols, W. E., 1991, Comparative Simulations of a Two-Layer Landfill Barrier Using the Help Version 2.0 and UNSAT-H Version 2.0 Computer Codes, PNL-7583, Pacific Northwest Laboratory, Richland, Washington.

47. Landeen, D. S., 1991, Animal Intrusion Status Report for Fiscal Year 1990, WHC-EP-0398, Westinghouse Hanford Company, Richland, Washington. 
48. Campbel1, M. D., G. W. Gee, R. R. Kirkham, S. J. Phillips, N. R. Wing, 1991, "Water Balance Lysimetry at A Nuclear Waste Site," in Proceedings of the International Symposium on Lysimetry, pp. 125-134, R. G. Allen (ed.), American Soc. Civil Engr., New York.

49. Kirkham, R. R., M. L. Rockhold, G. W. Gee, M. J. Fayer, M. D. Campbe11, and L. J. Fritschen, 1991, "Lysimeters: Data Acquisition and Analysis," in Proceedings of the International Symposium on Lysimetry, pp. 362-370, R. G. Allen (ed.), American Soc. Civil Engr., New York.

50. Phillips, S. J., J. F. Relyea, C. J. Kemp, N. R. Wing, M, D, Campbell, G. W. Gee, M. J. Graham, R. R. Kirkham, M. S. Rubin, 1991, "Development of Hanford Site Lysimeter Facilities," in Proceedings of the International Symposium on Lysimetry, pp. 19-27, R. G. Allen (ed.), American Soc. Civil Engr., New York.

51. Waugh, W. J., M. E. Thiede, L. L. Cadwe11, G. W. Gee, H. D. Freeman, M. R. Sackschewsky, J. F. Relyea, 1991, "Sma11 Lysimeters for Documenting Arid Site Water Balance," in Proceedings of the International Symposium on Lysimetry, pp. 151-159, R. G. Allen (ed.), American Soc. Civil Engr., New York.

52. Cadwe11, L. L. (Editor), 1991, Hanford Site Protective Barrier Development Program: Fiscal Year 1990 Highlights, PNL-7831, Pacific Northwest Laboratory, Richland, Washington.

53. Petersen, K. L., 1991, Modern and Pleistocene Climatic Patterns in the West, WHC-EP-0523, Westinghouse Hanford Company, RichTand, Washington.

54. Chatters, J. C. and H. A. Gard, 1991, Archaeological Mounds as Analogs of Engineered Covers for Waste Disposal Sites Literature Review and Progress Report, PNL-7718, Pacific Northwest Laboratory, Richland, Washington.

55. Sackschewsky, M. R., C. J. Kemp, L. L. Cadwe11, M. E. Thiede, and W. J. Waugh, 1991, Status Report for the Smal1-Tube Lysimeter Facility Fiscal Year 1990, WHC-EP-0381, Westinghouse Hanford Company, Richland, Washington.

56. Fayer, M. J., M. L. Rockhold, and D. J. Holford, 1992, Model Assessment of Protective Barriers: Part III Status of FY 1990 Work, PNL-7975, Pacific Northwest Laboratory, Richland, Washington.

57. Petersen, K. L., 1992, A Warm and Wet Little Climatic Optimum and a Cold and Dry Little Ice Age in the Southern Rocky Mountains, U.S.A., WHC-SA-1382-FP, Westinghouse Hanford Company, Richland, Washington.

58. Link, S. 0., J. L. Downs, M. E. Thiede, D. J. Lettau, T. R. Twadde11, and R. A. Black, 1992, Evapotranspiration Studies for Protective Barriers: FY 1990 Status Report, PNL-8032, Pacific Northwest Laboratory, Richland, Washington. 
59. Link, S. 0., M. E. Thiede, J. L. Downs, D. J. Lettau, and W. J. Waugh, 1992, Evapotranspiration Studies for Protective Barriers: FY 1989 Status Report, PNL-8033, Pacific Northwest Laboratory, Richland, Washington.

60. Fayer, M. J., M. L. Rockhold, and M. D. Campbe11, 1992, "Hydrologic Modeling of Protective Barriers: Comparison of Field Data and Simulation Resuits," Soil Science Society of America Journal, Vol 56 , No. 3, May-June 1992, pg. 690-700, Madison, Wisconsin.

61. Wing, N.R., 1992, A Peer Review of the Hanford Site Permanent Isolation Surface Barrier Development Program, WHC-MR-0392, Westinghouse Hanford Company, Richland, Washington.

62. Gee, G. W., M. J. Fayer, M. L. Rockhold, and M. D. Campbe11, 1992, "Variations in Recharge at the Hanford Site," Northwest Science, Vol 66, No. 4, 1992, pg. 237-250.

63. Ligotke, M. W., 1993, Soil Erosion Rates Caused by Wind and Saltating Sand Stresses in a Wind Tunnel, PNL-8478, Pacific Northwest Laboratory, Richland, Washington.

64. Fayer, M. J., 1993, Model Assessment of Protective Barriers: Part IV, Status of FY 1992 Work, PNL-8498, Pacific Northwest Laboratory, Richland, Washington.

65. Wing, N. R. and G. W. Gee, 1993, The Development of Permanent Isolation Surface Barriers: Hanford Site, Richland, Washington, U.S.A., WHC-SA-1799-FP, Westinghouse Hanford Company, Rich1and, Washington.

66. Petersen, K. L., J. C. Chatters, and W. J. Waugh, 1993, Long-Term Climate Change Assessment Study Plan for the Hanford Site Permanent Isolation Barrier Development Program, WHC-EP-0569, Rev. 1, Westinghouse Hanford Company, Richland, Washington.

67. Wing, N. R., The Results of Laboratory Tests to Determine the Physical Properties of Various Barrier Construction Materials, WHC-SD-ER-DP-006, Westinghouse Hanford Company, Richland, Washington. 
DOE/RL-93-27, Rev. 0

\section{DISTRIBUTION}

Number of Copies

Onsite

31

U.S. Department of Energy, Richland Field Office

J. K. Erickson (30)

A5-19

Public Reading Room

A1-65

1

Pacific Northwest Laboratory

Hanford Technical Library

$P 8-55$

48

Westinghouse Hanford Company

L. D. Arnold

B2 - 35

M. A. Buckmaster (28)

EDMC (9)

ERC (G. Fitzgibbon)

ERE (F. Stone) (2)

ERE Project File

ER Program Office (2)

IRA (3)

$\mathrm{H} 6-03$

H6- 08

H6- 07

H6-01

H6-03

Resource Center

H6-27

$\mathrm{H} 4-17$

N3-05 

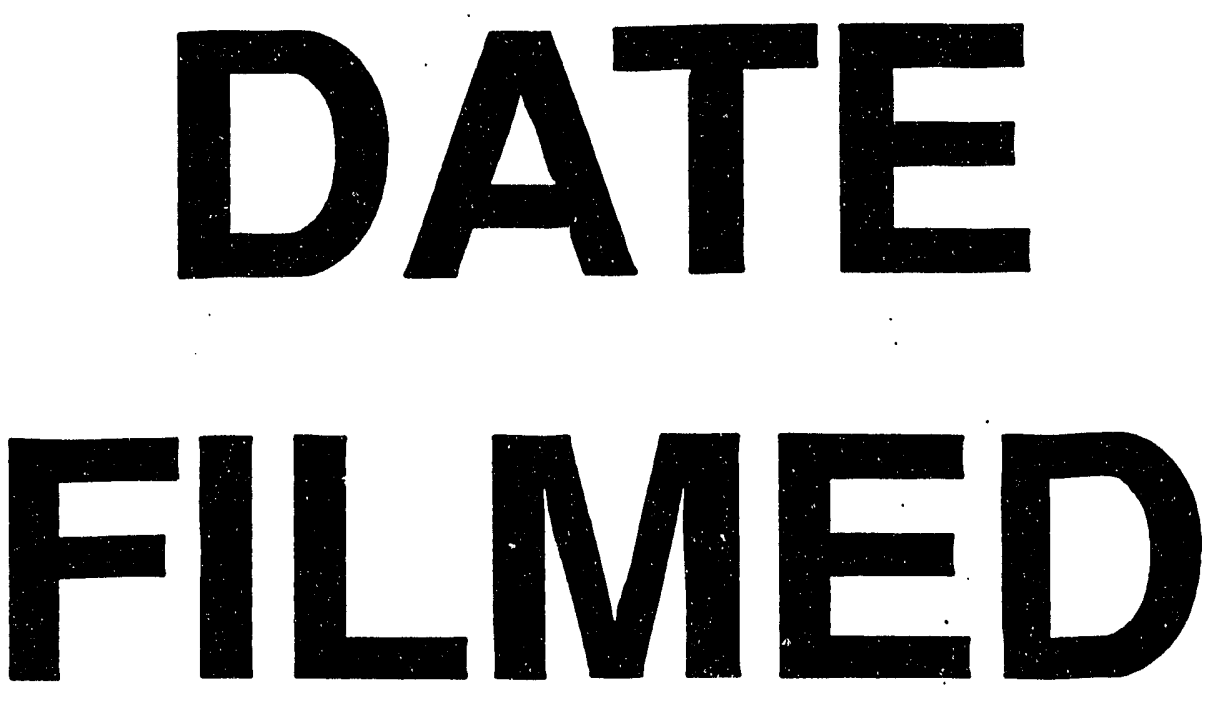

$11 / 17 / 93$
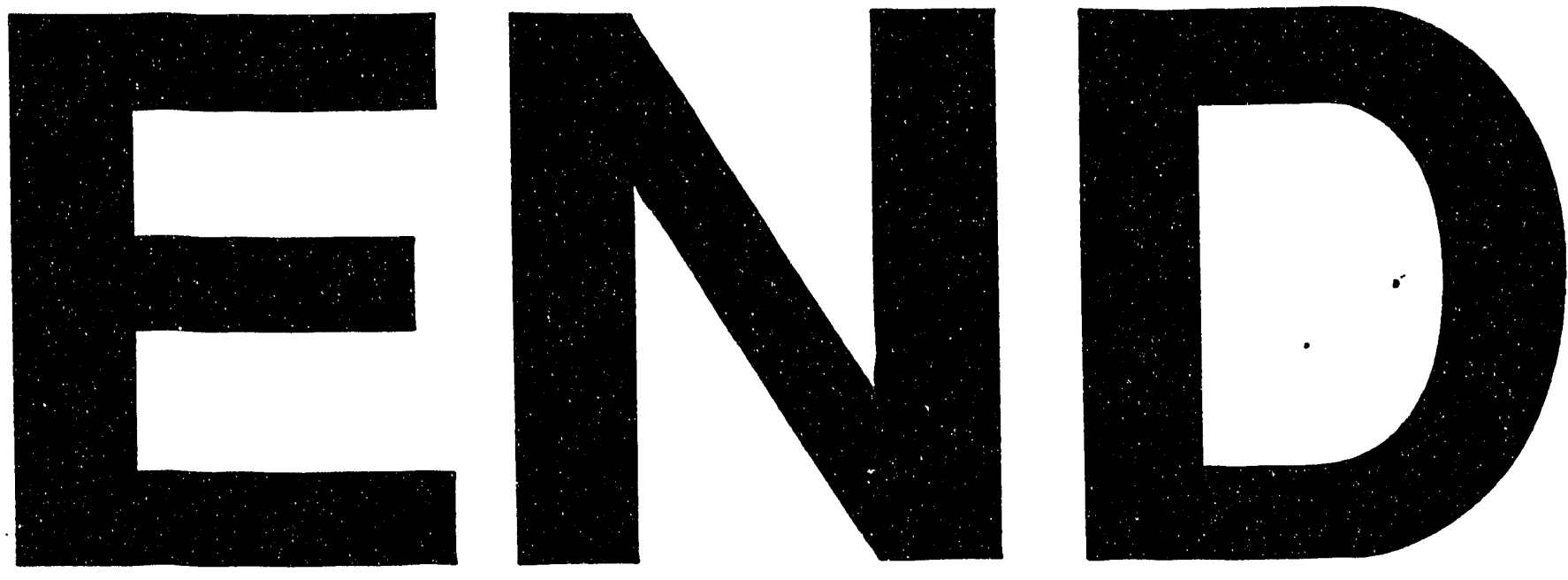
